Illinois State University

ISU ReD: Research and eData

Theses and Dissertations

10-14-2019

\title{
Exploring The Relationship Between Members Of Lifelong Learning Institutes And Host Institutions
}

Jon Charles Neidy

Illinois State University, jcneidy@gmail.com

Follow this and additional works at: https://ir.library.illinoisstate.edu/etd

Part of the Adult and Continuing Education Administration Commons, Adult and Continuing Education and Teaching Commons, Family, Life Course, and Society Commons, and the Higher Education Administration Commons

\section{Recommended Citation}

Neidy, Jon Charles, "Exploring The Relationship Between Members Of Lifelong Learning Institutes And Host Institutions" (2019). Theses and Dissertations. 1175.

https://ir.library.illinoisstate.edu/etd/1175

This Dissertation is brought to you for free and open access by ISU ReD: Research and eData. It has been accepted for inclusion in Theses and Dissertations by an authorized administrator of ISU ReD: Research and eData. For more information, please contact ISUReD@ilstu.edu. 


\section{EXPLORING THE RELATIONSHIP BETWEEN MEMBERS OF LIFELONG LEARNING INSTITUTES AND HOST INSTITUTIONS}

\section{JON CHARLES NEIDY}

\section{Pages}

The purpose of this study is to examine the relationship between an individual's involvement in Lifelong Learning Institutes (LLIs) and his or her propensity for philanthropic giving to the institute or its host college or university. The dataset was acquired through a survey administered to eleven Osher Lifelong Learning Institutes (OLLIs) in the United States. Data analysis was conducted on seven research questions which explored how the length, type, and frequency of participation, as well as the level of satisfaction, commitment, and feelings of community may relate to an LLI participant's inclination to donate. The findings of this study reveal these areas do influence the inclination to donate, regardless of alumni status. The results of this study encourage OLLI stakeholders to consider the findings during program and strategic planning.

KEYWORDS: continuing education, higher education administration, lifelong learning research, lifelong learning practice, philanthropy, older adults 


\title{
EXPLORING THE RELATIONSHIP BETWEEN MEMBERS OF LIFELONG LEARNING INSTITUTES AND HOST INSTITUTIONS
}

\author{
JON CHARLES NEIDY
}

A Dissertation Submitted in Partial

Fulfillment of the Requirements

for the Degree of

DOCTOR OF PHILOSOPHY

Department of Educational Administration and Foundations

ILLINOIS STATE UNIVERSITY 
Copyright 2019 Jon Charles Neidy 


\title{
EXPLORING THE RELATIONSHIP BETWEEN MEMBERS OF LIFELONG LEARNING INSTITUTES AND HOST INSTITUTIONS
}

\author{
JON CHARLES NEIDY
}

COMMITTEE MEMBERS:

Diane R. Dean, Chair

John K. Rugutt

Elizabeth T. Lugg 


\section{ACKNOWLEDGMENTS}

Gratitude is Given to Those Who Have Passed

George Crowl \& Earl Neidy - for tilling and toil

Lenora Crowl \& Gladys Neidy - for kindness and grace

Eric McClaren, Ph.D. - for inspiration and opportunity

Mike Fay - for practicality and persistence

Dev - for foresight and family

Chuck Neidy - for belief and belt buckles

Gratitude is Given to Those in the Present

Alma Dee Neidy - for love and gardens

Erik Neidy - for brotherhood and beginnings

Jennifer Neidy - for patience and love

Jane Neidy - for holidays and hope

Luke Neidy - for hope and history

Meghan Genovese - for strength and frissydom

Mark Schroll - for commitment and art

Erin Genovese - for sincerity and frissydom

Pete Magsig - for humor and humility

Stacy Peterson - for belief and time

Sean Genovese - for dungeons and dragons

Alicia Johnson - for inspiration and planning

Troy Johnson - for honor and humor

John McKinley - for consistency and jest

Jeremy Taylor - for concern and joy

Liza Decoteau - for editing and coherence

Alex Hertich, Ph.D. - for inspiration and cuisine

Paige Barney and Scott Cavanah - for listening and order bringing

Aimee and David Cook - for listening and sharing

Michelle Sharpswain, Ph.D. - for going first and love

Trent Halpin - for fortitude and questions

Matt Orndorff - for belief and leisure

Susan Ant - for contests and companionship

T.J. Klockenga - for commitment and leisure

Gail Raffel - for sharing and spaces

Gabrielle Healy - for good shoes and house elves

Dave Raffel - for commitment and caring

Bradley Raffel - for zombies and legos 
Neil Larimore - for encouragement and growth

Trevor Bryan - for rescue and candor

Eduardo Alvarado - for concern and levity

Barb Hansmeier - for beginnings and faith

Eulouise Williams - for baskets and inspiration

Kim Armstrong - for art and assurance

Janet Lange - for trust and opportunity

Wanda Lane - for support and kindness

Michelle Riggio - for responsibility and expertise

The Bradley University OLLI Gang - for inspiration and narrative

Staff of Continuing Education - for belief and joy

Molly Berger, Ph.D. - for conferences and martinis

John LaBrie, Ed. D. - for inspiration and opportunity

Laurel Hogue - for practicality and martinis

Cordelia Maloney - for grace and wisdom

Beth Laves, Ed. D. - for inspiration and commitment

Natalie Kokorudz - for dancing and grace

Colleagues of NCCSS \& NAASS - for opportunity and collegiality

Anne Hollis - for empathy and support

Nathan Thomas - for encouragement and opportunity

Judy Brown - for conviction and work ethic

Lisa Hinthorn - for handling and kindness

Janet Pesek - for care and concern

Rick Smith, Ph.D. - for asking and advice

Staff of the Smith Career Center - for patience and time

Jenny Burge - for grace and assessment

Greg Haines - for acorn and assessment

Kelly McConnaughay, Ph. D. - for trust and assessment

Kali Lightfoot - for origin and possibility

Steve Thaxton - for connections and opportunity

The OLLI National Resource Center Research Review Committee - for editing and opportunity

OLLI Directors and Members throughout the United States - for participating and sharing

Diane Dean, Ph.D. - for inspiration and patience

John Rugutt, Ph.D. - for statistics and insight

Elizabeth Lugg, J.D., Ph.D. - for possibility and legis

Donald Reid - for love and hope

J.C.N. 


\section{CONTENTS}

Page

ACKNOWLEDGMENTS

TABLES vii

CHAPTER I: INTRODUCTION TO THE STUDY 1

$\begin{array}{ll}\text { Overview } & 1\end{array}$

Background of the Problem 1

Purpose of the Study and Research Questions $\quad 2$

$\begin{array}{ll}\text { Conceptual Framework } & 3\end{array}$

Significance of the Study $\quad 4$

Overview of the Methodology $\quad 5$

$\begin{array}{ll}\text { Delimitations and Limitations } & 6\end{array}$

$\begin{array}{ll}\text { Definition of Terms } & 7\end{array}$

$\begin{array}{ll}\text { Organization of the Study } & 8\end{array}$

CHAPTER II: LITERATURE REVIEW 9

$\begin{array}{ll}\text { Overview } & 9\end{array}$

History \& Philosophy of Lifelong Learning $\quad 9$

Theoretical Foundations of Adult Learning and Older Adult Learning 10

Gerontagogy: Older Adult Learning 11

The Emergence of Formalized Programs for Older Learners 13

A Typology of Educational Programs for Older Learners 16

$\begin{array}{ll}\text { Key Characteristics } & 18\end{array}$

Generalizations from the Typology 22 
Lifelong Learning Institutes

Historical Evolution of Lifelong Learning Institutes

Emergence and Development of Osher Lifelong Learning Institutes

Participants and Market Growth of Lifelong Learning Institutes

Societal Needs Filled by Lifelong Learning Institutes

Participant Motivation in Lifelong Learning Institutes

The Learning that Occurs in Lifelong Learning Institutes

Organization-Public Relationships Theory

Summary

Overview

Research Questions

Research Design

Survey Research Method

Study Population

Study Sample and Sampling Procedures

Programs

Individuals

Instrumentation

Study Variables

Procedures

Data Analysis Procedures

Validity and Reliability 
$\begin{array}{ll}\text { External Validity } & 52\end{array}$

$\begin{array}{lr}\text { Internal Validity } & 52\end{array}$

$\begin{array}{lr}\text { Summary } & 53\end{array}$

$\begin{array}{ll}\text { CHAPTER IV: FINDINGS } & 54\end{array}$

$\begin{array}{ll}\text { Overview } & 54\end{array}$

Data Collection and Timeline $\quad 55$

Demographic Data and Descriptive Data 55

Reliability Analysis of Composite Variables $\quad 57$

$\begin{array}{lr}\text { Research Questions } & 59\end{array}$

Research Question 1: Length of Participation 59

$\begin{array}{ll}\text { Research Question 2: Alumni Relationship } & 60\end{array}$

Research Question 3: Type of Participation $\quad 60$

Research Question 4: Frequency of Participation 61

Research Question 5: Level of Satisfaction $\quad 62$

Research Question 6: Perceived Commitment 62

Research Question: 7 Perceived Communal Relationship 63

$\begin{array}{ll}\text { Factor Analysis } & 64\end{array}$

One-Way Analysis of Variance Analysis $\quad 64$

$\begin{array}{ll}\text { Discriminant Analysis } & 65\end{array}$

$\begin{array}{ll}\text { Summary } & 67\end{array}$

CHAPTER V: CONCLUSIONS AND IMPLICATIONS 68

$\begin{array}{ll}\text { Overview } & 68\end{array}$

$\begin{array}{lr}\text { Background } & 68\end{array}$ 
Limitations

Discussion of Findings

Recommendations

Areas for Future Study

Summary

REFERENCES

APPENDIX A: SURVEY PARTICIPATION AGREEMENT 


\section{TABLES}

Table

Page

1. Key Characteristics that Distinguish Lifelong Learning Models

2. Typology of Lifelong Learning Programs for Older Adults

3. Differences between Pedagogy, Andragogy and Gerontagogy

4. Length of Participation

5. Alumni Status

6. Leadership Roles

7. Volunteered

8. Participation in the Past 12 Months

9. Has Made One or More Financial Donations To

10. Instrument Subscales

11. Inclination to Donate by Years of Participation

12. Inclination to Donate by Alumni Status

13. Inclination to Donate by Leadership Service

14. Inclination to Donate by Volunteering

15. Inclination to Donate by Frequency of Participation

16. Correlation of Composite Variables

17. Rotated Component Matrix of Survey Items and Composite Variables

18. Group Means of Independent Variables

19. Unstandardized Discriminant Weights of the Instrument Composite Variables as Dependent Variable 


\section{CHAPTER I: INTRODUCTION TO THE STUDY}

\section{Overview}

This study proposes to examine the relationship between an individual's involvement in Lifelong Learning Institutes (LLIs) and his or her propensity for philanthropic giving to the institute or its host collegeor university. This chapter introduces the study by presenting the background of the research problem; the purpose of the study and research questions; the significance of the study; and an overview of the methodology including delimitations and limitations. Key terms used throughout the study are defined, and the chapter concludes with an outline of the overall organization of the study.

\section{Background of the Problem}

Higher education is an expensive enterprise, according to Bowen (1980), "each institution raises all the money it can" and "each institution spends all it raises" (p.20). In the seemingly endless quest for additional funding, some colleges and universities have determined that Lifelong Learning Institutes (LLIs) might be a good investment. These colleges and universities have recognized the population and societal trends in the United States and are developing LLIs in order to meet the perceived educational needs of an emerging population. This growing population of well-educated older adults, who will compose the voting and power majority of our society, may represent a new philanthropic opportunity for higher education. This opportunity can be examined through the theory of organization-public relationships (Broom, Casey, and Ritchey, 2000).

LLIs have emerged at colleges and universities throughout the United States as a response to the interests of an aging educated population and changing demographic trends. These LLIs are typically reflective of the local community and provide opportunities for both the older adult and the institution. Young (1992) comments, “These programs vary greatly in titles, 
location with the institution's table of organization, administration, structure curricular formats, and subject matter, size, cost, fee arrangements, and physical location, and in almost every other way imaginable" (p. 25). Although there is great variety in program structure, each of these programs represents a financial possibility for its sponsoring college or university. Miller (1992), supporting this idea, asserts that "elder learners will seek to actively use the institution's intellectual, artistic, and recreational resources... [while LLIs] may also stimulate their members to become patrons of the institution and, in time and with greater understanding, be motivated to share their material resources" (p. 4). The participants in these LLIs may become strong financial supporters of the colleges and universities in which they are housed and thereby help their host institution.

As the first broadly well-educated generation in the history of the US is beginning to retire, their continued desire to learn has the potential to positively impact their alma maters and local education providers. By creating LLIs in response to their new demand for continuing education, higher education institutions will be able to take advantage of the resulting philanthropic opportunities.

\section{Purpose of the Study and Research Questions}

The purpose of this study is to examine the relationship between an individual's involvement in Lifelong Learning Institutes (LLIs) and his or her propensity for philanthropic giving to the institute or its host collegeor university. The study will be guided by the following research questions:

Does length of participation in a Lifelong Learning Institute predict variance in individuals' inclinations to donate to the LLI or its hosting college/university? 
Does an alumni relationship with the host college or university predict variance in individuals' inclinations to donate to the LLI or its host collegeor university?

Does the type of participation in a Lifelong Learning Institute predict variance in individuals' inclinations to donate to the LLI or its host college or university?

Does the frequency of participation in a Lifelong Learning Institute predict variance in individuals' inclinations to donate to the LLI or its host college or university?

Does level of satisfaction with a Lifelong Learning Institute predict variance in individuals' inclinations to donate to the LLI or its host college or university?

Does perceived commitment to an LLI predict variance in individuals' inclinations to donate to the LLI or its host college or university?

Does a perceived communal relationship with a LLI predict variance in individuals' inclinations to donate to the LLI or its host college or university?

\section{Conceptual Framework}

Road Scholar (formerly Elderhostel) indicates that they have "built the largest network of Lifelong Learning Institutes (LLIs) across the U.S., helping adults pursue their love of learning close to home and facilitating the development of new curriculum and collaboration among our network of hundreds of LLIs." They go on to state that they "work closely with the administrators and members of the more than 400 LLIs in our network to develop and share educational resources that help fulfill our shared educational missions." These LLIs have been developing since 1962 (Kim and Merriam, 2004), and many aspects of their participants have been researched. These aspects include concepts such as motivation of participants (Lamb and Brady, 2005, Linnehan and Naturale, 1998, Kim and Merriam, 2004), preferred instructional methods (Clark, Fochs Heller, Rafman, and Walker, 1997, Hiemstra, 1998, Merriam, 2001), and 
the creation of LLI programs (Miller, 1992). However, there has been minimal research on the potential philanthropic opportunities inherent in the creation of a LLI at a college or university. The use of organization-public relationship theory can help to illuminate this opportunity for higher education and will serve as a foundation for examining the dynamics of this philanthropic opportunity. A concise definition of organization-public relationship theory was provided by Broom, Casey, and Ritchey,

Organization-public relationships are represented by the patterns of interaction, transaction, exchange, and linkage between an organization and its publics. These relationships have properties that are distinct from the identities, attributes, and perceptions of the individuals and social collectivities in the relationships. Though dynamic in nature, organization public relationships can be described as a single point in time and tracked over time. (p. 18)

Jo, Hon, and Brunner utilized organization-public relationship theory in their 2004 study titled Organisation-Public Relationships: Measurement Validation in a University Setting. They attempted to “test empirically Hon and Grunig's proposed organisation-public relationship instrument" (p. 14). Organization-public relationship theory also was used by Waters in 2008 "to measure the relationships non-profit organisations develop with their annual giving and major gift donors and to compare the differences between the giving levels" (p. 75).

\section{Significance of the Study}

Although there have been both qualitative and quantitative studies done of LLIs as an emerging phenomenon in higher education, the available literature which examines the relationship between the LLI provider and the LLI participant is scarce. The researcher will provide a brief history and commentary on the growth of LLIs both in the United States and 
globally, investigate differing program structures of LLIs, and explore motivation factors for participation. An exploration of Organization-Relationship Theory allows the researcher to situate the exploration of the relationship between individual participants of an LLI and their host institution.

By reviewing the growth and structures of LLIs, exploring the relationships that LLI participants develop with their host institutions, and examining member inclination to donate to host institutions, researchers may become more informed about the potential for increased philanthropy. In addition, LLI program administrators can better articulate the potential for their programs within the structure of the host institution.

\section{Overview of the Methodology}

This study relies on a quantitative, predictive, nonexperimental design to "describe and measure the degree or association (or relationship) between two or more variables" (Creswell, 2014, p. 12); and to "generalize from a sample to a population so that inferences can be made about some characteristic, attitude, or behavior of this population" (p.146). Given the relationship construct between individuals and organizations, an experimental design is neither feasible nor advisable. The survey will be cross-sectional, in that data will be collected from multiple participants in different locations at one point in time. Gay and Airasian state that, "a cross-sectional survey involves the collection of data from selected individuals in a single time period" (Gay \& Airasian, p. 279). Cross-sectional design is identified by Cresswell as one that will "examine current attitudes, beliefs, opinions, or practices" (2008, p. 389). He goes on to explain that "attitudes, beliefs, and opinions are ways in which individuals think about issues, whereas practices are their actual behaviors" (2008, pp.389-390). This survey will compare both the participants' beliefs and their behaviors regarding their individual experiences with Lifelong 
Learning Institutes. This study will use various statistical analyses to compare composite variables with selected demographic variable and regression analysis for predictive purposes and to answer the identified research questions.

\section{Delimitations and Limitations}

The delimitations of this study "are those characteristics that limit the scope and define the boundaries" (Simon, M. K. 2011, p.2). Although there are many forms of lifelong learning programs, and they are found at nearly all types of colleges and universities, the researcher has chosen to delimit the study by focusing on $\boldsymbol{O}$ sher Lifelong Learning Institutes, those funded by the Bernard Osher Foundation and which are required as a result of their funding to make annual reports to the Bernard Osher Foundation and also engage in fundraising activities. This

delimitation will ensure that potential participants at least have had some exposure or familiarity with the fundraising construct. As a result, the generalizability of this study is limited to Osher Lifelong Learning Institutes. In addition Hon and Grunig's Organization-Public Relationship Theory will serve as a delimiter to provide a specific lens through with to view the connections of individual LLI participants to their LLIs.

Limitations refer to conditions that restrict or weaken generalizability because they cannot be controlled as part of the design. This study relies upon survey research. "Survey research is a non-experimental research approach used to gather information about the incidence and distribution of, and the relationships that exist between, variables in a predetermined population. Its uses include the gathering of data related to attitudes, behaviours and the incidence of events. For most modern researchers sample surveys are more cost effective and easier to undertake than population surveys when gathering information; however, this increases 
the risk of both representation and measurement errors" (Coughlan, Cronin, \& Ryan, 2009, p.10).

This study is limited to the LLI participants who agree to participate and complete the online survey. Each participant's familiarity with his or her college or university serves as another limitation to this study.

\section{Definition of Terms}

Several terms used in the study may be unfamiliar to the reader. These are defined here in alphabetical order to clarify the specific meaning of terms and to reduce misconceptions.

Alumni Status indicates whether or not an LLI participant is an alumnus of the host college or university.

Feelings of community refers to the sense of belonging that LLIs engender in participants in relationship to the host college or university.

Give and inclination to give refer to the willingness of an LLI participant to donate financially to the host college or university.

Institute for Learning in Retirement (ILR) refers to a group of older learners typically gathered at a college or university in classes of their own for the pursuit of knowledge. This term is synonymous with Lifelong Learning Institute and Learners of the Third Age.

Learners of the Third Age refers to a group of older learners typically gathered at a college or university in classes of their own for the pursuit of knowledge. This term is synonymous with Institute for Learning in Retirement and Lifelong Learning Institute.

Lifelong Learning Institute (LLI) refers to a group of older learners typically gathered at a college or university in classes of their own for the pursuit of knowledge. This term is synonymous with Institute for Learning in Retirement and Learners of the Third Age. 
Older Learners are defined as anyone who attends a Lifelong Learning Institute.

\section{Organization of the Study}

This chapter provided an overview of the study by introducing the research problem, the questions the study will address, and the methodology that will be used. The next chapter, "Literature Review," discusses the relevant areas of scholarship, writing, and theoretical constructs that provide the context and foundation for the study. Chapter three, "Methodology," describes the research design in detail.

The completed study will contain two additional chapters. Chapter four, "Data Analysis," will present and analyze the data collected, and Chapter five, "Discussion, Conclusion and Recommendations," will synthesize and apply the results to address the study's research questions, discuss these results in the context of the underlying research problem, and develop implications for theory and practice. The completed study will conclude with suggestions for future research. 


\section{CHAPTER II: LITERATURE REVIEW}

\section{Overview}

This chapter provides a review of selected literature related to the study. It begins with a comprehensive overview of the history and philosophy of lifelong learning, defining the term and laying out the theoretical foundations of adult learning and older adult learning. Next it reviews the emergence of formalized programs for older learners, offering a typology of programs for older learners according to key categories of program characteristics.

Generalizations from the typology are considered. Then, focusing on one program type for adult learners, the chapter presents the historical evolution of Lifelong Learning Institutes (LLIs), discussing who participates in LLIs and why, the learning that occurs there, and what societal needs are filled by LLIs.

\section{History \& Philosophy of Lifelong Learning}

This section defines lifelong learning and presents the history, growth, and philosophy of the lifelong learning program movement in the context of Lifelong Learning Institutes (LLIs). Lifelong learning is defined by the U.S. Department of Education National Center for Education Statistics (2000) as "at its broadest and most theoretical level [as] a process or system through which individuals are able and willing to learn at all stages of life, from preschool years through old age" (p. 4). This definition serves the U. S. Department of Education purposes, but the phrase "lifelong learning" has also become a euphemism specifically to describe and define education for older adults in the United States, to replace synonymous phrases that used words such as “senior" or "elder" primarily because "programs targeted specifically toward seniors or older adults would...[not] catch their attention because they [do not]... identify themselves as part of that population. Terms such as "third age" and "lifelong learning" are [more] appealing to older 
adults across age cohorts because they imply a continuum of learning" (American Council on Education, 2008, p. 3). Throughout this study, the term "lifelong learning" is used exclusively to refer to education for older adults.

\section{Theoretical Foundations of Adult Learning and Older Adult Learning}

Within the United States, Malcolm Knowles is largely credited with developing and popularizing andragogy: the central component of adult learning theory. Andragogy: Adult and continuing education, according to Merriam and Brockett (2007), can be defined as "activities intentionally designed for the purpose of bringing about learning among those whose age, social roles, or self-perception, define them as adults" (p. 8). In the United States, adult education is often associated with adult learning theory, "a mosaic of theories, models, set of principles, and explanations that combined, compose the knowledge base of adult learning ... two important pieces of that mosaic are andragogy and self-directed learning” (Merriam, 2003, p.3). The concept is frequently used to refer to postsecondary education or training that is intended for adults who are beyond the age range of traditional undergraduate college students (18-25) or traditional graduate students (25-34). Andragogy's central premise is that adults learn differently from children. The theory "presents core principals of adult learning that in turn enable those designing and conducting adult learning to build more effective learning processes for adults" (Knowles, Hilton \& Swanson, 2005, p. 2).

Although the theory of andragogy is firmly rooted and has a wide following, it remains a contested concept. In their introduction to the seventh edition of The Adult Learner, Knowles, Holton, and Swanson (2011) comment, "Since the earliest days, adult educators have debated what andragogy really is... it has been described as a set of guidelines (Merriam, 1993), a philosophy (Pratt, 1993), a set of assumptions (Brookfield, 1986), or a theory (Knowles, 1989)" 
(p. 1). More recently, andragogy is being recast as simply "student-directed learning" and now represents just one of a range of teaching approaches (from teacher-directed to student-directed) that may be used with any individual, with its appropriateness determined more by content and context than by age (Hanson, 1996; Merriam, Cafarella \& Baumgartner, 2007).

\section{Gerontagogy: Older Adult Learning}

Often thought of as distinct subset or outgrowth of adult education, the theoretical foundation of education for older adults is somewhat more difficult to identify within the literature. In Education for older adults, Glendenning (2001) made a profound statement about the literature surrounding the origins and purposes of education for older adults,

Throughout this process there has been the unspoken assumption that education is 'a good thing' and that is why we engage in it. This does not begin to answer the question of legitimation, or lack of it. One reason for this failure to develop is that the body of knowledge about third age education has never got beyond the anecdotal. What has never been a priority is the exploration with older learners as to why, for some, education in later life has proved to be an essential ongoing experience. Nor have those who have facilitated learning for older people been persuaded to reflect on their own experience and so to share their views about content, process and methodology with a wider audience. There still is no such accessible body of knowledge from which it is possible to draw realistic conclusions. (p. 68)

In this statement, Glendenning hits upon the silently pervasive societal attitudes concerning the value of older adults. As he points out, society assumes it is a valuable practice to educate individuals throughout much of their lifespans. For example, early childhood education (in pre-schools or in the home) is widely practiced in the United States, and elementary and 
secondary education is compulsory from ages five through eighteen. Post-secondary education, although not compulsory, has reached levels of mass participation; and public policy aims toward reaching universal participation. Graduate education, workforce education, and continuing education are all strongly promoted for adults to continue learning and developing throughout their working years. Yet such interest and encouragement evaporates once adults exit the workforce and enter the third age. The implicit assumption may be that older adults, near the end of their lifespans, are not in need of further educational investment. Perhaps this is why individuals in that age-range adopt self-identifying terms like "third age" in order to subvert the negative connotations associated with terms such as "senior" or "elderly."

Regardless of the underlying rationale, a deficit in the learning continuum is apparent at the end of the spectrum represented by older adults. Filling that void, "Educational gerontology is one of the most recent additions to the growing list of terms that are beginning to form the categories and subcategories of the field of study and practice related to the processes of human aging" (Peterson, 1985, p. 1). A developing field in higher education, the discipline "began after 1950 primarily as an extension of existing adult education efforts" and focuses on the scholarship and practice of specific educational programming for older learners (Hiemstra, 1998, p.6). The field of educational gerontology has blossomed into having its own organizations, conferences, and journal.

Despite the growth in educational gerontology's popularity, scholars such as Lemieux and Martinez (2000) claim that it falls short of being a true learning theory. The concept, they assert, focuses more on the physical phenomenon of aging rather than the processes of relating to older adults in a teaching/learning dynamic. In a quest to extend learning theory across the lifespan, Lemieux and Martinez (2000) "maintain that the study of older adults in a situation of 
teaching/learning necessitates original and specific ideas" (p. 482). The authors propose the term gerontology "as a new hybrid science resulting from the prolific combination of educational gerontology - a multidisciplinary specialization in itself_—and education of the aging” (p. 482). In sum gerontagogy - a learning theory for the aged that is, itself, in its infancy - represents the merging of gerontology and adult education, "the two knowledge bases from which the interplay of retirement and education can be studied" (Walker, 1996, p. 39). Like the theoretical construct of andragogy, the concept of gerontagogy continues to be debated in the research literature as scholars struggle to define and distinguish the term, its purposes, and applications.

\section{The Emergence of Formalized Programs for Older Learners}

The characteristics that distinguish formalized programs for older adult learning - also known as lifelong learning programs - from other adult and continuing education programs are that they; (a) are intended for older adults and b) do not award academic credit or continuing education units. The history and development of such programs is diffuse, although some forms - such as Lifelong Learning Institutes - have given greater attention to their own history than others. What is clear is that by the mid-twentieth century, formalized learning programs for older adults were expanding in their number and form. The now defunct Adult Education Association of the United Stated of America, in their 1955 Education for Later Maturity: A Handbook (Donahue) asserts that "Adult educators were the first professional group in education to recognize the implications of an aging population for their field" (p. v). "[I]t was evident," Donahue notes, "that interest in the role of adult education in the preparation of adults for living a full and satisfying life during later maturity was growing in every section of the country" (p. v). The proliferation of such programs had grown to an extent that "there was an apparent need for a handbook describing the content and organization of programs already underway” (p. v). 
Furthermore, "in view of the growing numbers of older persons" at that time, coupled with changes in American worklife and society that yielded greater leisure time, there was "some interest attached to the question of whether or not formal educational activities with direct appeal to older persons and designed to meet their needs may not greatly increase" (Anderson, 1955, p.60).

The federal government was also adding to the national discourse on the learning needs of older adults through "The White House Conference on Aging [which] occurs once a decade to make aging policy recommendations to the President and Congress, and to assist the public and private sectors in promoting dignity, health, independence and economic security of current and future generations of older persons" (U.S. Department of Health and Human Services Administration on Aging: About the Conference). One consideration should be that the federal government - which has attended to the financial security, housing, and health care needs of older adults - has also recognized the need to address the insufficiency of learning needs for this population. Manheimer and Moskow-McKenzie (1995) credit The 1971 White House Conference on Aging with some of the growth in the "number and quality of educational programs for older adults" (p. 613).

A question remained, however, regarding what sponsoring entity would be the organizing force behind formalized programs for older adult learning. The provision of and policies for formalized education in the United States has traditionally been left to state oversight, including programs at the early-childhood, elementary, secondary, postsecondary, and workforce development levels. These have been supplemented with private non-profit and for-profit offerings, which are also subject to local regulatory oversight. 
Anderson (1955) suggested positioning older adult learning as an outgrowth of higher education,

One suggestion is that of organizing a separate college or a division with a university for older persons. In such a division they would feel at home, would meet others with similar interests and aspirations, and would not be embarrassed by being the only old persons in classes with hundreds of normal undergraduate age. (p. 60)

However, sixty years later it is apparent that the development of such divisions has not been extensive in higher education. "[G]rowth of older learner programs can only be partially attributed to the academic field of gerontology, the activities of adult education organizations, or the initiative of government agencies... The rise of older learner programs has been a grassroots phenomenon ... at the local level" (Manheimer, 2008, pp. 111 -112). This may be partly attributable to the legitimation issue with older adult learning theory as articulated in the previous section. Writing specifically about “The marginality of adult education," Clark (1958) observed "Adult education enterprises are marginal because of their relative position and status within [a college or university] administrative structure" (p. 2). This marginality persists today, with older adult education even more marginalized than adult education. "One could argue that, for the United States, older learner programs play a marginal role relative to both academic gerontology and adult education, and that neither field has captured the dramatic emergence of this movement" (Manheimer, 2008, p. 112).

Fortunately, the lack of legitimation in older adult education may be changing as a result of demographic shifts. Sara Lawrence Lightfoot (2009) succinctly summarizes this when she asserts, 
U.S. Census statistics from 2000 tell the story of a recent and significant bulge in the population of older Americans who are healthier, better educated and yearning for a productive and enjoyable alternative to retirement. ... In the twenty-first century another phase of life seems to be emerging as significant and distinct, capturing our interest, engaging our curiosity, and expanding our understanding of human potential and development. (pp. 9 -10)

Lightfoot refers to this phase of life as the "Third Chapter" (p. 10) and believes that "we are beginning to redefine our views about the casualties and opportunities of aging; we are challenging cultural definitions of strength, maturity, power and sexiness" (p. 10).

\section{A Typology of Educational Programs for Older Learners}

Andragogy, adult learning theory, and educational gerontology can all be credited with the theoretical beginnings of educational programs for older learners. Now more than 50 years old, the growth and development of such offerings led to the creation of distinctly different forms of programs and entities. A nascent field of research in higher education, our knowledge about the organization and administration of programs for older learners is meagre. A typology is needed to bring clarity to our understanding and discussion. This section offers such a typology, comparing and contrasting the defining characteristics of educational programs for older adults.

As Mills and Margulies (1980) explain, "the notion of a typology as it pertains to organizations, organisms, or an entity, can be essentially viewed as a multidimensional classification of the entities it attempts to depict [Blau \& Scott, 1962]" (p. 255). They assert that typologies "play an important role in theory development because valid typologies provide a general set of principles for scientifically classifying things or events...to generate an analytical tool or instrument, not only as a way of reducing data, but more significantly to stimulate 
thinking" (p. 255). Although Mills and Margulies (1980) were specifically addressing the development of a typology for service organizations, their beliefs about organizations apply to learning programs for older learners as well; they affirm that "organizations are not unlike any other phenomena...they possess certain common characteristics as well as unique idiosyncrasies" (p. 255).

Manheimer, Snodgrass, and Moskow-McKenzie's Older Adult Education: A Guide to Research, Programs, and Policies (1995) offers a basis for the creation of a typology of lifelong learning entities. In their guide, the authors identify five models of older adult education in the United States. These are:

1. Lifelong Learning Institutes (www.roadscholar.org/ein/intro.asp)

2. OASIS Institutes (www.oasisnet.org/Home.aspx)

3. Shepherd's Centers (www.shepherdcenters.org)

4. Community Colleges (http://plus50.aacc.nche.edu/Pages/Default.aspx)

5. Senior Centers (www.ncoa.org/strengthening-community-organizations/senior-centers/nisc/) Manheimer et al. (1995) selected these five models because they "have shown distinctive growth, stability, and innovation during the past two to three decades" (p. 84). Each serves the learning needs of older adults through various programming methodologies.

Since the publication of their guide, the world has experienced an explosive growth in the use of computers and the internet. Distance-learning and social-media are now firmly woven into the fabric of society. As a result of this change, a sixth model of older adult education, SeniorNet, has gained widespread use in the United States. Founded in 1986, SeniorNet addresses the computer technology needs of older learners throughout the United States and offers lifelong learning opportunities over the internet (www.seniornet.org). It is worth inclusion 
with Manheimer, Snodgrass, and Moskow-McKenzie's (1995) five models as it has shown distinctive growth, stability, and innovation.

\section{Key Characteristics}

These six models vary in their configuration of nine key characteristics; who, what, when, where, why, and how - that define each entity. The "who" characteristic includes the participant profile ("who" participates), administration ("who" manages it), and sponsoring organization(s) ("who" sponsors it). The "what" characteristic consists of the programs the entity(ies) provides. The "when" and "where" characteristics comprise the schedule ("when" programs are offered) and location ("where" programs are offered). The explicit motivation or mission of each entity is its "why" characteristic. The final characteristic, the "how," includes curricular construction and funding ("how" the entity's curriculum is developed and "how" it finances its operations). Table 1 provides a simple and brief description of these characteristics.

Table 1

Key Characteristics that Distinguish Lifelong Learning Models

\begin{tabular}{|c|c|c|}
\hline & Characteristic & Description \\
\hline WHO & Participant Profile & $\begin{array}{l}\text { The characteristics of the learners who attend or the } \\
\text { phrase typically used to describe them }\end{array}$ \\
\hline WHO & Administration & The local leadership of the program \\
\hline WHO & Sponsoring Organization (s) & $\begin{array}{l}\text { The national and local entities with which the program } \\
\text { is associated }\end{array}$ \\
\hline WHAT & Programs Provided & The size and content of the learning \\
\hline WHEN & Schedule & The frequency or typical schedule of the offerings \\
\hline WHERE & Location & The place where the learning occurs \\
\hline WHY & Explicit Motivation & The stated or expressed goals of the program \\
\hline HOW & Curricular Construction & The process by which the learning is created \\
\hline HOW & Funding & The monetary source(s) of the program \\
\hline
\end{tabular}

Applying these characteristics to the aforementioned six models yields a typology that simplifies complex amounts of information and facilitates comparisons of lifelong learning 
programs for older adults (Table 2). The descriptions of each model's characteristics derive from information on the entity's website. 
Table 2

Typology of Lifelong Learning Programs for Older Adults

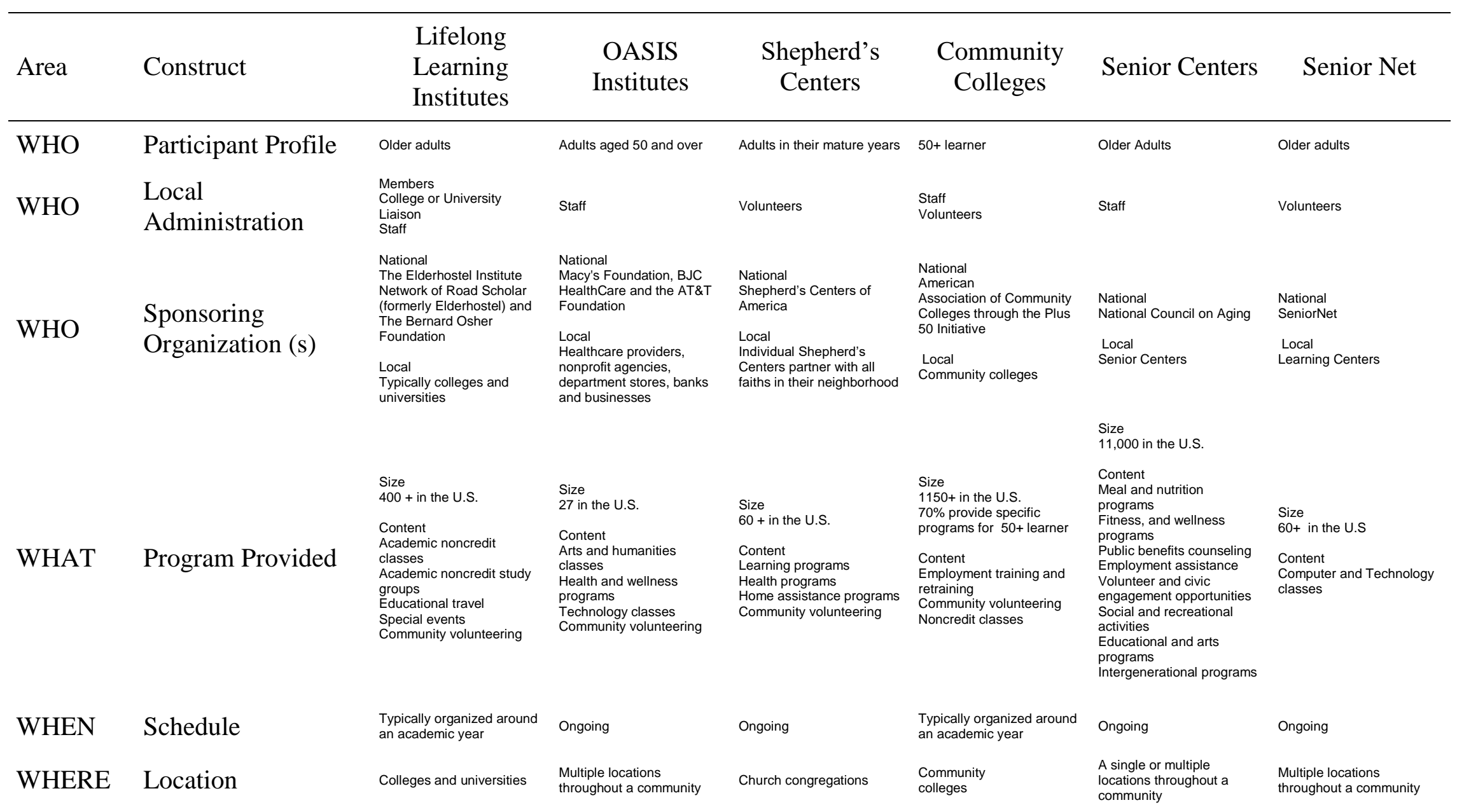

(Table Continues) 
Table 2, Continued

Typology of Lifelong Learning Programs for Older Adults

\begin{tabular}{|c|c|c|c|c|c|c|c|}
\hline Area & Construct & $\begin{array}{l}\text { Lifelong } \\
\text { Learning } \\
\text { Institutes }\end{array}$ & $\begin{array}{l}\text { OASIS } \\
\text { Institutes }\end{array}$ & $\begin{array}{l}\text { Shepherd's } \\
\text { Centers }\end{array}$ & $\begin{array}{l}\text { Community } \\
\text { Colleges }\end{array}$ & Senior Centers & Senior Net \\
\hline WHY & $\begin{array}{l}\text { Explicit } \\
\text { Motivation }\end{array}$ & $\begin{array}{l}\text { LLLs offer a unique } \\
\text { educational opportunity in } \\
\text { which peer learning, } \\
\text { collaborative leadership, and } \\
\text { active member participation } \\
\text { are fundamental. } \\
\text { A commitment to learning is } \\
\text { the common bond among } \\
\text { the many thousands of } \\
\text { energetic and enthusiastic } \\
\text { LLI members. }\end{array}$ & $\begin{array}{l}\text { Our mission is to enrich the } \\
\text { lives of mature adults by } \\
\text { engaging them in lifelong } \\
\text { learning } \\
\text { and service programs so } \\
\text { they can learn, lead and } \\
\text { contribute in their } \\
\text { communities. }\end{array}$ & $\begin{array}{l}\text { All Shepherd's Centers } \\
\text { share a commonly } \\
\text { understood mission to } \\
\text { empower older adults to use } \\
\text { their wisdom and skills for } \\
\text { the good of their } \\
\text { communities. And, they } \\
\text { provide health enhancement, } \\
\text { cultural enrichment and } \\
\text { lifelong learning } \\
\text { opportunities. }\end{array}$ & $\begin{array}{l}\text { Through the AACC Plus } 50 \\
\text { Initiative community colleges } \\
\text { create or expand campus } \\
\text { programs to engage the } 50+ \\
\text { population in learning; } \\
\text { training or re-training } \\
\text { programs; and volunteer, } \\
\text { civic, or service activities. }\end{array}$ & $\begin{array}{l}\text { Senior centers serve as a } \\
\text { gateway to the nation's aging } \\
\text { network-connecting older } \\
\text { adults to vital community } \\
\text { services that can help them } \\
\text { stay healthy and } \\
\text { independent. }\end{array}$ & $\begin{array}{l}\text { SeniorNet's mission is to } \\
\text { provide older adults } \\
\text { education for and access to } \\
\text { computer technologies to } \\
\text { enhance their lives and } \\
\text { enable them to share their } \\
\text { knowledge and wisdom. }\end{array}$ \\
\hline HOW & $\begin{array}{l}\text { Curricular } \\
\text { Construction }\end{array}$ & $\begin{array}{l}\text { The curriculum is typically } \\
\text { chosen, designed, and often } \\
\text { led by volunteer faculty and } \\
\text { members. }\end{array}$ & $\begin{array}{l}\text { There are several national } \\
\text { curricular packages. } \\
\text { Some of the curriculum is } \\
\text { chosen, designed, and led } \\
\text { by volunteers. }\end{array}$ & $\begin{array}{l}\text { The curriculum and projects } \\
\text { are typically chosen, } \\
\text { designed, and led by } \\
\text { volunteers. }\end{array}$ & $\begin{array}{l}\text { There are several national } \\
\text { curricular packages. } \\
\text { Model programs are } \\
\text { provided as resources. } \\
\text { Most of the curriculum is } \\
\text { typically chosen, designed, } \\
\text { and often led by paid faculty } \\
\text { and staff. }\end{array}$ & $\begin{array}{l}\text { There are several national } \\
\text { curricular packages. } \\
\text { Model programs are } \\
\text { provided as resources. } \\
\text { Most of the curriculum is } \\
\text { typically chosen, designed, } \\
\text { and often led by paid staff. }\end{array}$ & $\begin{array}{l}\text { There are several national } \\
\text { curricular packages. } \\
\text { The classes are typically } \\
\text { chosen and led by } \\
\text { volunteers. }\end{array}$ \\
\hline HOW & Funding & $\begin{array}{l}\text { State Funding (for public } \\
\text { colleges and universities) } \\
\text { Private Funding (for private } \\
\text { colleges and universities) } \\
\text { Private Donations } \\
\text { Foundation Grants } \\
\text { Membership and } \\
\text { Participation Dues }\end{array}$ & $\begin{array}{l}\text { Foundation Grants } \\
\text { Corporate Grants } \\
\text { Government } \\
\text { Grants } \\
\text { Private Donations }\end{array}$ & $\begin{array}{l}\text { Private Donations } \\
\text { Congregational Donations }\end{array}$ & $\begin{array}{l}\text { State Funding } \\
\text { The AACC Plus } 50 \text { Initiative } \\
\text { is funded with a } \$ 3.2 \text { million } \\
\text { dollar grant from The Atlantic } \\
\text { Philanthropies. }\end{array}$ & $\begin{array}{l}\text { To maintain operations, } \\
\text { senior centers must leverage } \\
\text { resources from a variety of } \\
\text { sources. These include } \\
\text { federal, state, and local } \\
\text { governments; special events; } \\
\text { public and private grants; } \\
\text { businesses; bequests; } \\
\text { participant contributions; in- } \\
\text { kind donations; and } \\
\text { volunteer hours. Most } \\
\text { centers rely on } 3 \text { to } 8 \\
\text { different funding sources. }\end{array}$ & $\begin{array}{l}\text { A national, } 501 \text { (c) } 3 \text { nonprofit } \\
\text { organization with } \\
\text { international affiliates, } \\
\text { SeniorNet is funded by } \\
\text { membership dues, Learning } \\
\text { Center fees, the altruistic } \\
\text { donations of individuals, and } \\
\text { the generous support and } \\
\text { sponsorship of corporations } \\
\text { and foundations. }\end{array}$ \\
\hline
\end{tabular}




\section{Generalizations from the Typology}

A review of the typology offers several broad generalizations for lifelong learning programs for older adults. In terms of WHO participates in, administers, and sponsors the programs: Older adults are being defined as 50 and older, and participants are found in all socioeconomic levels. Program administration varies among organizations but typically is handled by either staff or volunteers. All of the programs are affiliated with and/or sponsored by a national association but are strongly committed to the needs of their local constituents. Among the national associations, Senior Centers provide the most program locations whereas OASIS Institutes provide the fewest.

In terms of WHAT the entities offer, and WHEN and WHERE they offer it: There is much diversity found in the classes and programming each model offers. For example, one of the programs only provides computer and technology training. Several emphasize civic engagement and volunteering. Similarly, there is little commonality in terms of where programming occurs. Only two of the six models (1/3) are housed exclusively within colleges and universities. Rather than investing in infrastructure, all but one of the programs partner with other entities for classroom and program space. Likewise, programming occurs throughout the year with little similarity in the calendars of offerings. The exception is the two programs associated with colleges and universities, which do typically follow the academic calendar of their hosts.

The WHY and HOW characteristics: A common feature among the explicit motivations of these lifelong learning entities includes the idea of empowering older adults and emancipating them from societal stereotypes of aging. Given the wide variation in specific programming offered, the great differences found in the construction and delivery of curriculum are not surprising. Some programs have national curricular models which they follow; most are entirely 
dependent on local development. Although the entities have diverse funding bases, most receive operational support from foundations.

This typology and associated generalizations serve as a valuable resource for discussion of, research on, and planning for educational programming for older adults. Within this study, it provides important context for a focused discussion of Lifelong Learning Institutes.

\section{Lifelong Learning Institutes}

Of the six models of educational programming for older adults, this study focuses on one of two models situated within colleges and universities: Lifelong Learning Institutes (LLIs). Lifelong Learning Institutes are typically hosted by colleges or universities and provide noncredit academic learning programs for people ages 50 and over. "These programs vary greatly in titles, location within the institution's table of organization, administration, structure curricular formats, and subject matter, size, cost, fee arrangements, and physical location, and in almost every other way imaginable" (Young, 1992, p. 25). While there is much variety in the construction and administration, they all share a belief that learning for older adults belongs within an academic environment.

\section{Historical Evolution of Lifelong Learning Institutes}

The origin of LLIs as educational programming for older adults dates back at least five decades. One such organization, the Elderhostel Institute Network (EIN) indicates that "The first LLI was the Institute for Retired Professionals (IRP) established in 1962 at the New School in New York City" (A Brief Overview of the LLI Movement). It was born of grassroots organizing when "A group of 152 retired New York City schoolteachers under the leadership of Hy Hirsch, founded a scholarly home for themselves in Greenwich Village where they organized a learning community at the School of Social Research" (Hebestreit, 2006, p. 54). 
The growth of LLIs was slow until the 1980s (Fischer, Blazey, \& Lipman, 1992). “[T]hroughout the 1960's and 1970's other colleges and universities replicated or adapted the IRP [Institute of Retired Professionals] model. During the 1980's several national conferences introduced the concept to a wider audience and spurred the development of many more groups" (A brief overview of the LLI movement, n.d.). Between 1962 and 1988 the number continued to grow in the United States: by the end of that decade, "A 1989 survey by the National University Continuing Education Association reveal[ed] the existence of more than 161 different memberdriven programs for older adults in the United States" (Fischer, Blazey, and Lipman, 1992, p.18). These 161 member-driven programs were operated independently at various colleges and universities. However, they were not associated with each other in any formal way.

In 1988, thirty of those programs "collaborated with Elderhostel, Inc. to form a voluntary association known as the Elderhostel Institute Network (EIN)" (Merz Nordstrom, n.d.). The establishment of EIN encouraged the creation of new institutes, provided resources, and developed a national organization for LLIs (Merz Nordstrom, n.d.). The EIN has been successful in its support of establishing new LLIs.: from its inception in 1988 to 2008, the organization grew 120\%. As of January 29, 2009, the Elderhostel Institute Network website listed 369 organizations (Find a Lifelong Learning Institute, n.d.) in the United States. Currently, the organization lists that number as "more than 400" (Lifelong Learning Institutes \& Road Scholar, n.d.).

\section{Emergence and Development of Osher Lifelong Learning Institutes}

More recently, The Bernard Osher Foundation began funding non-credit lifelong learning programs throughout the United States called Osher Lifelong Learning Institutes (OLLIs). The following history from The Bernard Osher Foundation website 
(www.osherfoundation.org/index.php?olli, 2017) identifies how these emerged on the national stage.

In the fall of 2000, the [Bernard Osher] Foundation began to consider programs targeted toward more mature students not necessarily well served by standard continuing education curricula. Courses often attract students of all ages eager to accumulate units to complete degrees or to acquire specific job skills. By contrast, the interest of many older adults, especially those who have retired, is in learning for the joy of learning - without examinations or grades - and keeping in touch with a larger world.

The Foundation was fortunate to have two immediate examples of successful lifelong learning programs to inform its deliberations. One was the Fromm Institute of Lifelong Learning at the University of San Francisco; the second was Senior College at the University of Southern Maine in Portland.

First Grants: In early 2001, an endowment grant was given to the University of Southern Maine to improve and extend its excellent programs, and the name "Senior College" was changed to “Osher Lifelong Learning Institute.” Shortly afterward, Sonoma State University, a member of the California State University (CSU) system became a grantee. Both programs progressed admirably, and the Foundation decided to enter the "lifelong learning" field in a significant fashion.

National Expansion: Beginning in the fall of 2002, the Foundation issued Requests for Proposals to campuses in the California State University and University of California 
systems. Grants of $\$ 100,000$ were made on the understanding that once a lifelong learning institute was launched, the Foundation would consider renewal of the grant for two or more years with a view to providing an endowment gift of no less than $\$ 1$ million if the institute was able to demonstrate potential for success and sustainability.

At present, the Foundation supports 120 lifelong learning programs on university and college campuses across the country, with at least one grantee in each of the 50 states and the District of Columbia. The Foundation also supports a National Resource Center for Osher Institutes which is located at Northwestern University.

Current Program: The Foundation has not been highly prescriptive in the type of lifelong learning program it has chosen to support. While there is considerable variation among the Osher Institutes, common features remain prominent: Non-credit educational programs specifically designed for seasoned adults aged 50 and older; strong support from the leadership of the university or college; a diverse repertoire of intellectually stimulating courses; robust volunteer leadership; established mechanisms for evaluating participant satisfaction with educational offerings; and sound organizational structure. The characteristics shared by all Osher Institutes strengthen the possibility that the individual institutes will become not only successful but programmatically and financially sustainable. The designation of each grantee as "The Osher Lifelong Learning Institute at the University of X" is a condition of the Foundation's grant-making as is the use of a logo consisting of a simple circle with the words "Osher Lifelong Learning Institute" arranged within. 
The Bernard Osher Foundation's significant financial contributions to these programs have certainly helped in the evolution of LLIs on a national level.

\section{Participants and Market Growth of Lifelong Learning Institutes}

LLIs as an educational phenomenon are a result of changes in cultural attitudes about older adults and changes in the demographics of the United States. As the population ages a vast market for learning programs that address their specific learning needs is created. The older adults who choose to participate in LLIs do so for a variety of reasons, but primarily because of their commitment to learning and to meet social needs. Despite being located at institutions of higher education, the learning is different from traditional forms of higher education.

Society currently views higher education primarily as an opportunity for young adults to prepare themselves for employment. This paradigm is only sustainable as long as society is willing to support it. The growing population of older adults, who compose the voting and power majority, may force higher education to reconsider that construct. Kressley and Huebschmann (2002) summarize the impending situation with,

The elderly population of the United States is growing rapidly. This growth is fueled by a number of factors, perhaps most significant of which is increased life expectancy rates made possible by medical advances. Bacon-Blood estimates that there are currently more than 33 million Americans age 65 and older, and that number is expected to grow to 69 million by 2030 and 80 million by 2050 (Bacon-Blood, 1998). Those over 65 accounted for $13 \%$ of the population in the mid-90s, but that percentage is expected to double within 30 years (Kressley, 1998). These numbers will continue to grow as the leading edge of the babyboom generation approaches the age 65 milestone within the next ten years. 
Another area that will be impacted by this booming population of senior citizens is education. As people are living longer lives, and in some cases retiring earlier, the number of active retirement years is correspondingly increasing. Senior citizens are seeking new ways to spend this time in meaningful ways. Their true challenge is not to find activities that simply fill time, but rather to find ones that are personally fulfilling and lead to a sense of satisfaction. (pp. 838-839)

More recently, Eisen (2005) commented, "Current projections indicate that the number of Americans over age sixty-five will almost double in the next twenty-five years rising from approximately 12 percent now to 22 percent of the entire population by $2030 \ldots$ we are in store for an explosion in the number of learners over age sixty" (Eisen, p. 16). Additionally, in The Changing Demographic Profile of the United States (2006), the Congressional Research Service indicated that by the year 2025 those aged 65 and over will comprise $18.2 \%$ of the entire population. This represents a $10 \%$ increase since 1950 . It is clear that the United States is headed for a vast swelling in the size of its older adult population, and who will be a better educated senior citizenry than that in previous generations.

It is important to note that this opportunity is different from the fears of the "adverse effects of population decline" (Vedder, 2004, p. 17) which many colleges and universities responded to the 1970s. In contrast, the greying of the United States population does not foreshadow a potential loss of enrollment, but rather a new opportunity for a different kind of student in the context of a cultural shift. This new type of student, the adult learner, is not necessarily seeking grades or academic credit, but is looking for a community of learners who share a similar passion for education. 
While there will be a larger number of older adults, not all will choose to participate in a lifelong learning program. This is supported by Kim and Merriam (2004) when they report, Historically, older adults have been underrepresented in formal adult education activities. Valentine's (1997) analysis of U.S. participation found that although approximately $43 \%$ of adults under age 54 participate in adult education, only $26.3 \%$ of $55-64$-year olds did. The percent is even smaller among adults over 65 years of age. And while the latest government estimates of adults participating in education reveal that nearly $50 \%$ are involved in formal education, adults over 65 have a participation rate of about 30\% (U.S. Department of Education, 2001). Nevertheless, it is clear from these statistics that the rate of participation for older adults is increasing. (p. 445) In her dissertation, Learning in retirement institutes: The impact on the lives of older adults, Martin (2002) asserts that "research demonstrates that there is a 'typical' older adult learner" (p. 57). She states "The demographic profile of a typical older adult participating in learning programs at institutions of higher education would describe a white female with a high level of education, a middle to high income, and in self-reported good health...the age of such learners can range from 50s-90s" (p. 57). Her assertion is supported by Kim and Merriam (2004) when they state, "studies on older adult participation in educational activities reveal that socioeconomic status is a major correlate of participation in learning activities. Most adults, including older learners participating in educational activities are white, middle class, welleducated, and financially secure (Merriam \& Caffarella, 1999; Valentine, 1997)" (p. 448). According to their research the other strong indicator of participation is "level of previous education ... The more education one has, the more likely one is to seek learning opportunities" (p.448). 
The first broadly well-educated population of older adults in the United States will continue to search for purpose in retirement. It is foreseeable that they will seek that purpose in learning at institutions of higher education. This may present an opportunity for institutions of higher education as Manheimer (2008) asserts,

Considering the near-term future, as a correlate to these trends, lifelong learning opportunities will increasingly become a function of the marketplace. Those who are in sufficiently good health, are motivated by having enjoyed prior years of education (the main predictor of participation), and can afford to enroll in LLIs, pay for travel-learning excursions, sign up for continuing education courses, register for back-to-campus alumni seminars, access Internet educational sites, and choose from among a cornucopia of other lifelong learning programs, will reap the benefits of "successful aging." (p. 123)

It is evident that the market for such programs is emerging and will continue to grow. It is also evident that programs like LLIs are fulfilling an important need.

\section{Societal Needs Filled by Lifelong Learning Institutes}

Manheimer (2008) asks a question regarding the importance of lifelong learning for older adults when he queries, "What about people who are winding down careers or who have retired? Does society continue to have a stake in their further education, or are they now on their own, free of social obligations and norms and, therefore, no longer the concern of national governments?" (pp. 113 -114). According to Manheimer (2008), the answer to this question is better found abroad than in the United States. He states, "In France and other European countries and Japan, national and regional governments play major roles in managing lifelong learning for people of all ages, and institutions of higher education strongly influence their curricula and pedagogy" (p. 113). Some parts of the industrialized international community believe in 
education for older adults and support programming for them. Many national governments view the education of older adults much in the same way that they view the education of children, as a societal necessity. The aging population has received much international attention over the past decade and is a global reality. In 2002 the United Nations General Assembly convened the second World Assembly on Aging. Their Executive Summary (2001) presents four major findings:

Population ageing is unprecedented, without parallel in the history of Humanity; Population ageing is pervasive, a global phenomenon affecting every man, woman and child. Population ageing is profound, having major consequences and implications for all facets of human life; and Population ageing is enduring. During the twentieth century the proportion of older persons continued to rise, and this trend is expected to continue into the twenty-first century. For example, the proportion of older persons was 8 per cent in 1950 and 10 per cent in 2000, and is projected to reach 21 per cent in 2050. (p. xxviii)

In addition to the United Nations, other organizations are examining this emerging trend. For example, the National Institute on Aging (2007) contends that "Despite the weight of scientific evidence, the significance of population aging and its global implications have yet to be fully appreciated" (p. 1). Globally, future cohorts of the aging population will continue to be increasingly better educated. Kinsella and He in An Aging World (2009) note, “...today’s younger people have a much higher literacy rate than the older population, implying that future cohorts of older people will be more literate" (p. 94) and hopefully become lifelong learners.

LLIs provide an educational outlet for this literate and better educated citizenry and thereby encourage the participants to continue to contribute to their communities. This continued 
contribution is frequently realized through the promotion or coordination of volunteer activities at LLIs, in local school districts, at local nonprofits, and civic entities. LLIs and lifelong learning itself are also important to society for two additional reasons, the beneficial aspects of cognitive engagement and of a positive social setting, which, fortunately, coincide with participant motivation for involvement.

\section{Participant Motivation in Lifelong Learning Institutes}

According to Kim and Merriam (2004), "The motives of older adults for learning are arguably complicated and multidimensional. Rarely does a single motive lead older adults to participate in educational activities. Generally, both external and internal forces influence the decision of older adults to pursue learning" (p. 445). Fortunately, the research literature provides strong evidence to support the ideas of learning and socialization as the primary motivational factors. According to Lamb and Brady the factors for attending an LLI have been debated since the 1983 National Adult Education Conference when James Fisher presented his paper, "What Turns Older Adults on to Education” (Lamb \& Brady, 2005). Their article cites Brady and Fowler as determining "that studies going back to 1971 are generally consistent in finding that cognitive interests (desire to know) are the most often cited reasons for participation in adult education" (Lamb \& Brady, 2005, p. 210). The belief that that desire to know or to learn is the primary reason for participation is supported in Kim and Merriam's quantitative study which "confirms that older learners are more influenced by cognitive interest to engage in learning than by any other factors" (Kim \& Merriam, 2004, p. 452). Kim and Merriam (2004) maintain that cognitive interests are most often found in the well-educated, "Apparently the educated mind seeks to satisfy intellectual curiosity. Highly educated elderly people who want stimulating activities participate in learning activities because they are interested in knowledge itself and find 
learning joyful" (p. 452). Finally, Kim and Merriam (2004) summarize previous studies when they assert "Several studies suggest that the strongest motivations among older students are cognitive interest (intellectual curiosity) and a desire to learn" (Brady \& Fowler, 1988; Bynum \& Seaman, 1993; Furst \& Steele, 1986; Russett, 1998; Scala, 1996; Wolfgang \& Dowling, 1981) (p. 446).

The secondary reason for participation is the desire for social interaction. Fischer, Blazey, and Lipman note that "the strongest motive for older adults' participation in education is the desire to establish vital new social connections to feel needed and wanted, and to have a really good reason for daily human interaction" (Fischer, et al., 1992, p. 17). Deakin, Crick and Wilson, reflecting on the work of Dewey and Vygotsky, posit that

The formation of an individual learner and socio-cultural activities are mutually constituting processes. Thus the nature of the social environment in which a learner finds herself and the quality of learning relationships in which she participates have a significant impact on her development as a learner. (Deakin Crick and Wilson, 2005, p. 361)

Linnehan and Naturale (1998) comment, "social interaction is encouraged in various ways, through structured (recreation), unstructured, and formal gatherings" (p.32). In the same article Linnehan and Naturale state, "ILRs [another acronym for LLIs] provide a uniquely supportive environment. The members of a group are intensely interested, do not have any reticence about expressing their views, and are never bored" (p.32).

Many other researchers in the field of adult education have also noted similar observations. As Clark, Heller, Rafman, and Walker (1997) remark, "the greatest source of 
satisfaction for many is the interaction with other participants...many members mention that this informal setting contributes to their satisfaction. Learning in a relaxed atmosphere with peers...takes away the stress often experienced in the regular classroom" (p. 753-754).

The theme of community support is found in many studies about older adults' participation in LLIs. For example, a qualitative study conducted by Lamb and Brady found the “experience of OLLI [Osher Lifelong Learning Institute] as a supportive community....[where] members had enrolled initially to meet other people, once they began attending they found that it was a safe place to take intellectual and emotional risks" (Lamb \& Brady, 2005, p. 217). In the same study Lamb and Brady support Linnehan and Naturale's idea of social interaction being encouraged in various ways (Linnehan \& Naturale, 1998) by commenting, "Many students found the OLLI practice of having lunch together greatly enhanced the sense of community...much of the lunch discussion seems to be a follow up to what has gone on in class" (Lamb \& Brady, 2005, p. 218). The concepts of learning and community are inherently linked in the LLI research. Lamb and Brady summarize this linkage in the following passage:

Belonging to a community is a core component in the successful LLI experience. Much of the reason why older people sang the praises of their program and expressed passion for the myriad ways their LLI has enriched their lives is because their experience was situated in a safe and nurturing community - a community in which teachers and students work together as equals and colearners. It is also a community in which enough trust is established in a reasonable short period of time that people feel comfortable sharing deep and personal communications with each other. Finally, it is a community in which both wealthy and working-class persons, people with Ph.D.s and G.E.D.s, men and women, people 55 and 95 years of age, and individuals with wide variation in religious and ethnic 
backgrounds can sit side-by-side in classrooms and work happily and productively together. (Lamb \& Brady, 2005, p. 221-222)

\section{The Learning that Occurs in Lifelong Learning Institutes}

Learning is the reason most often cited by LLI attendees for continued attendance, but it is different from traditional higher education. While the class content is typically college level, the courses are taken on a non-credit basis and "the curricula are chosen, designed, and often led by organization members [who] encourage peer learning and active member participation (Kim \& Merriam, 2004, p. 442). In their 1992 book, Students of the Third Age, Fischer, Blazey, and Lipman provide a practical approach to the creation of "Learning-in-Retirement programs" (p.

18) and specifically note that

members select either subjects of current interest, or those which had a long-time appeal...[they] want courses and study groups of consequence...free from the pressures of examinations or testing....[they] favor programs to which they can bring insights gained in their work careers and life experiences. They want to contribute to the learning process; to share with others the special ways of looking at or information that varied experiences have given them. (Fisher et al., 1992, pp. 53-54)

The idea that participants are responsible for designing and facilitating their own learning opportunities is one that guides most LLIs and sets them apart from traditional learning environments. The concept of self-directed learning originated at the earliest LLI, the Institute of Retired Professionals at the New School in New York City. The current Director of the New School reflecting on the development of their teaching and learning process describes it as "a unique community of peer learners, all sharing responsibility for the program. Every member 
was a curriculum creator, learning leader, and student" (retrieved May 31, 2012, from www.newschool.edu/institute-for-retired-professionals/about/).

This novel learning dynamic now found at LLIs throughout the country could be described by the term Lemieux and Martinez (2000) espoused: gerontagogy. Their call for this new theory is summarized with,

Thus, as educational gerontology signifies that the elderly learns [sic] in a different way than do younger adults, we must then find methods that correspond to the learning of the senior learner. The whole of these new methods, techniques, etc., regrouped in a new corpus of knowledge, will give birth to the emergence of this science named gerontagogy. (p. 492)

Gerontagogy differs from both pedagogy and andragogy in how teaching and learning are manifested in the environment. According to McGrath (2009), pedagogical theory "assumes that the student will simply learn what they have been told" (p. 100) and "that the teacher's job was to fill the students minds with their own information and the students were not encouraged to question what they were being taught" (p. 101). She also asserts that, "Some people would associate pedagogy solely with children, but surprisingly it can also be associated with adult learning" (p. 100). McGrath (2009) maintains that adult learning is better realized through the idea of andragogy which "unlike pedagogy... is centered on the idea that the lecturer does not possess all the knowledge and that students are encouraged to participate in the classroom by utilising [sic] their own experiences" (p. 102). According to McGrath (2009), in andragogy "adults are allowed to analyse [sic] the material given to them in the classroom and they learn to make connections between the material and their own life experiences" (p. 102). 
Pedagogy, andragogy, and gerontagogy can be additionally differentiated from each other by examining learner motivations. In a pedagogical environment, learners are typically present because society expects them to be: children and adolescents are expected to attend school. Their motivation is almost entirely external. In an andragogical environment, learners are typically present because of a desire to advance in their professions, as an expectation of the employer or from a compelling desire to know something more. Their motivations could be described as both internal and external. Finally in a gerontagogical environment, learners are typically present because of profound desire to learn. In the continuum of their lifetime learning they have moved beyond both societal expectations and work expectations for learning. Their motivation is entirely internal, and they participate because they enjoy the process of learning and the acquisition of new knowledge. The key gerontagogical practices that appear to distinguish lifelong learning from traditional forms of postsecondary instruction include a lack of an external reward structure (credits or grades), participant-selected topics for study (through participation in curriculum committees), and a profound attention to the social aspect of learning (through planned social breaks during the learning experience). The differences found between pedagogy, andragogy, and gerontagogy are illustrated in Table 3. 
Table 3

Differences between Pedagogy, Andragogy and Gerontagogy

\begin{tabular}{|c|c|c|c|}
\hline & Pedagogy & Andragogy & Gerontagogy \\
\hline $\begin{array}{l}\text { Demands of } \\
\text { Learning }\end{array}$ & $\begin{array}{l}\text { Learner can devote more } \\
\text { time to the demands of } \\
\text { learning because } \\
\text { responsibilities are minimal. }\end{array}$ & $\begin{array}{l}\text { Learner must balance life } \\
\text { responsibilities with the } \\
\text { demands of learning. }\end{array}$ & $\begin{array}{l}\text { Learner can devote more } \\
\text { time to the demands of } \\
\text { learning because many life } \\
\text { responsibilities have been } \\
\text { fulfilled. }\end{array}$ \\
\hline $\begin{array}{l}\text { Role of } \\
\text { Instructor }\end{array}$ & $\begin{array}{l}\text { Learners rely on the } \\
\text { instructor to direct the } \\
\text { learning. Fact based } \\
\text { lecturing is often the mode } \\
\text { of knowledge transmission. }\end{array}$ & $\begin{array}{l}\text { Learners are autonomous } \\
\text { and self-directed. Teachers } \\
\text { guide the learners to their } \\
\text { own knowledge rather than } \\
\text { supplying them with facts. }\end{array}$ & $\begin{array}{l}\text { Learners are exploring and } \\
\text { engaging in topics of } \\
\text { personal interest. Instructors } \\
\text { can lecture, facilitate, or } \\
\text { guide. }\end{array}$ \\
\hline $\begin{array}{l}\text { Life } \\
\text { Experiences }\end{array}$ & $\begin{array}{l}\text { Learners are building a } \\
\text { knowledge base and must } \\
\text { be shown how their life } \\
\text { experiences connect with } \\
\text { the present learning. }\end{array}$ & $\begin{array}{l}\text { Learners have a } \\
\text { tremendous amount of life } \\
\text { experiences. They need to } \\
\text { connect the learning to their } \\
\text { knowledge base. They must } \\
\text { recognize the value of the } \\
\text { learning. }\end{array}$ & $\begin{array}{l}\text { Learners have a tremendous } \\
\text { amount of life experiences. } \\
\text { They need to connect the } \\
\text { learning to their knowledge } \\
\text { base. They recognize and } \\
\text { embrace the value of the } \\
\text { learning. }\end{array}$ \\
\hline $\begin{array}{l}\text { Purpose for } \\
\text { Learning }\end{array}$ & $\begin{array}{l}\text { Learners often see no } \\
\text { reason for taking a } \\
\text { particular course. They just } \\
\text { know they have to learn the } \\
\text { information. }\end{array}$ & $\begin{array}{l}\text { Learners are goal oriented } \\
\text { and know for what purpose } \\
\text { they are learning new } \\
\text { information. }\end{array}$ & $\begin{array}{l}\text { Learners enjoy the process } \\
\text { of learning along with the } \\
\text { content of the learning. They } \\
\text { are participating to learn and } \\
\text { grow. }\end{array}$ \\
\hline $\begin{array}{l}\text { Permanence } \\
\text { of Learning }\end{array}$ & $\begin{array}{l}\text { Learning is compulsory and } \\
\text { tends to disappear shortly } \\
\text { after instruction. }\end{array}$ & $\begin{array}{l}\text { Learning is self-initiated and } \\
\text { tends to last a long time. }\end{array}$ & $\begin{array}{l}\text { Learning is self-initiated and } \\
\text { may or may not last a long } \\
\text { time. The act of learning } \\
\text { may be more important than } \\
\text { the content. }\end{array}$ \\
\hline
\end{tabular}

adopted and adapted from http://coe.sdsu.edu/eet/Articles/andragogy/start.htm

Differences in terminology and the lack of an agreed-upon professional term to refer to older adult learning demonstrate how the lifelong learning movement is still very much evolving. For example, the terms geragogy or gerogoy also appear in the research literature to describe the educational process for older adults. The terms appear as definitions in Bastable, Gramet, Jacobs, and Sopczyk 2010 book, Health Professional as Educator: Principles of Teaching and Learning. As they state, "the teaching of older persons known as gerogogy, is different from teaching younger adults (andragogy) and children (pedagogy)" (2010, p. 180). Lemieux and Martinez 
(2000) believe that gerontagogy is a better term to describe the teaching and learning that occurs at an LLI because,

The terms geragogy and geriagogy have the same etymological definition, that is "geros" elderly, 'agogia' behaviour, and have a medical consonance, because they have the same root as the term 'geriatrics. It is then legitimate to claim that geragogy deals with the learning of the elderly presenting deficits which fall within geriatrics. From this viewpoint, geriatrics appears as being the theoretical base of geragogy. It is evident that we cannot use the term geragogy in order to describe learning of the elderly who do not have deficits falling within geriatrics. (p. 492)

Unfortunately, this issue of nomenclature has not been resolved. However, it may reflect differences that are more geographical than substantive. As Formosa (2002) points out, "The term 'gerogogy' which refers to the practical teaching strategies employed in older adult education has been used in European academic discourse since the 1950s" (p. 75). Thus it is not surprising that Lemieux, who hails from Canada, and Martinez, who hails from Spain, prefer the use of this and similar terms.

Regardless of the professional language used to define adult learning sciences, what is clear is that the number of lifelong learning participants in the United States will inevitably increase as our population ages and more people who are better educated retire. In turn, the increased number of people who are seeking lifelong learning opportunities will lead to the creation of more programming that can help keep our aging citizenry engaged in society and cognitively. Older adults who choose to participate will typically do so because of their interest in learning and the social benefits they receive from participating. The learning they will 
experience at LLIs will be different from that found traditionally in higher education venues and may help to challenge our beliefs about the teaching and learning process for students of all ages.

\section{Organization-Public Relationships Theory}

Organization-Public Relationships Theory, which originates in the field of public relations, provides a foundation by which researchers and practitioners can examine the relationships that LLIs (as organizations) develop with their public (the member participants). A concise definition of organization-public relationship theory was provided by Broom, Casey, and Ritchey (2000),

Organization-public relationships are represented by the patterns of interaction, transaction, exchange, and linkage between an organization and its publics. These relationships have properties that are distinct from the identities, attributes, and perceptions of the individuals and social collectivities in the relationships. Though dynamic in nature, organization public relationships can be described as a single point in time and tracked over time. (p. 18)

They identify ten tentative conclusions about the theory:

1. Public relations researchers and practitioners can study relationships as phenomena distinct from the perceptions held by parties in the relationships.

2. The formation of relationships occurs when parties have perceptions and expectations of each other, when one or both parties need resources from the other, when one or both parties perceive mutual threats from an uncertain environment, or when there is either a legal or voluntary necessity to associate. 
3. Relationships consist of patterns of linkages through which the parties in them pursue and service their interdependent needs.

4. Relationships are the dynamic results of the exchanges and reciprocity that manifest themselves as the relationships develop and evolve, yet they can be described at a given point in time.

5. Relationships may lead to increased dependency, loss of autonomy, goal achievement, and structured interdependence in the form of routine and institutionalized behavior.

6. Relationships have unique and measurable properties that are not shared with the participants in the relationships and that define relationships as being something separate from the participants.

7. The antecedents and consequences of relationships also have unique properties that distinguish them from the relationship.

8. Relationship formation and maintenance represents a process of mutual adaptation and contingent responses.

9. The absence of a useful definition precludes measurement of organization-public relationships and forces both scholars and practitioners alike to measure one part of them or another and make potentially invalid inferences about the relationships.

10. The absence of a fully explicated conceptual definition of organization-public relationships limits theory building in public relations. (pp. 16 -17)

These tentative conclusions can help the administrator or researcher better understand the theory and gain a greater appreciation for the power of the relationship that develops between the organization and individual members of the public. 
Jo, Hon, and Brunner utilized organization-public relationship theory in their 2004 study titled Organisation-Public Relationships: Measurement Validation in a University Setting. They attempted to "test empirically Hon and Grunig's proposed organisation-public relationship instrument" (p.14) which explored "the relationship students have with the undergraduate university they choose to attend" (pp. 16 -17). According to the researchers,

This research effort was designed to (1) empirically test Hon and Grunig's proposed OPR instrument and (2) test-retest the instrument using two studies with different subjects and time. Although each of the two data sets displayed slightly different operationalised items, the two groups of subjects similarly perceived the six-factor measures as a valid and reliable instrument for measuring their relationship with the university. (p. 23) Organization-Public Relationship Theory was also used by Waters in 2008 "to measure the relationships non-profit organisations develop with their annual giving and major gift donors and to compare the differences between the giving levels." (p.76) Waters (2008) asserts, "after nearly one decade of studying relationships, public relations literature provides a scholarly framework for studying the non-profit organisation-donor relationship that includes valid and reliable scales and precedence for hypotheses" (p. 77). In this study Waters (2008) sought to determine whether a donor's evaluation of the Organization-Public Relationship (OPR) could be used to predict whether the donor gave during the most recent fundraising campaign (p. 79).

The combination of organization-public relationship theory and a modified version of an OPR instrument would allow a researcher to empirically test the strength of relationships that LLI participants develop with the LLI and the host institution along with their inclination to donate. This may help to validate their presence on college and university campuses, in addition to encouraging additional LLIs to be created throughout the United States. 


\section{Summary}

Planning, changing, and leading LLIs is an engaging challenge for administrators of higher education. A thoughtful planning process, paired with an appropriate understanding of the change process and clearly defined benchmarks or goals can create a mutually beneficial relationship for the host institution and individual LLI participants. Leading such an organization requires a specialized skill set that draws on multiple leadership theories as well as an understanding of Organization-Public Relationships Theory.

As evidenced by the explicit commentary and tacit assumptions in the preceding sections, lifelong learning is an important construct for individuals, higher education, and society. It is often used to describe and define education for older adults in the United States that provides opportunities for cognitive enrichment and growth in a societal setting. Using the term "lifelong learning" helps to dispel myths and negative connotations about aging and encourages all individuals to view education as a lifetime pursuit as those who participate are engaged in educational environments of their own design that reflect their own personal interests and inclinations.

Lifelong learning is an important construct for higher education because it provides opportunities for the institution to be perceived as "giving back" to the community and to engage potential new donors in academic life. By engaging LLI participants in intergenerational programming, institutions of higher education thereby impact their traditionally aged undergraduate students in new ways. This can also create opportunities to engage alumni who are not inclined to participate in sporting events.

Society can benefit from an active lifelong learning community both economically and through volunteerism. An energetic and engaged older citizenry who are well informed and 
connected to current events and technology are more inclined to volunteer in myriad community settings thereby providing rich generational memory, and, most importantly, by sharing their collective wisdom with younger generations.

More research is needed to support the ways in which investing in LLIs can be mutually beneficial for the host institution and the individual member participants. This study will address that knowledge gap by examining the relationship between an individual's involvement and his or her propensity for philanthropic giving back to the institution. 


\section{CHAPTER III: RESEARCH METHODOLOGY}

\section{Overview}

At colleges and universities throughout the United States new programs for retirees are emerging in the form of Lifelong Learning Institutes (LLIs). While cognitive development and the joy of learning are the primary reasons that older adults participate in continuing education, the research literature provides strong evidence that the desire for social interaction and relationships are nearly equally strong motivators (Clark, et al., 1997; Fischer, et al., 1992; Lamb $\&$ Brady, 2005). Lifelong Learning Institutes meet both needs, providing opportunities for older adults to learn and create connections with each other. LLIs differ markedly from traditional college courses in that the curricula and offerings are predominately student designed and controlled, and emphasize peer-learning (Kim \& Merriam, 2004). This high level of engagement with and ownership over the curricula may foster strong bonds between individual participants and between participants and the institute. Many LLIs intentionally strive to create and enhance these relationships.

The purpose of this study is to examine the relationship between member involvement in LLIs and the propensity for philanthropic giving to the institute or its host college or university. Using Hon and Grunig's organization-public relationship framework (1999), the study seeks to

understand how the length, type, and frequency of participation, as well as level satisfaction and feelings of community relate to an LLI participant's inclination to donate. This chapter describes the methodology of the study, presenting the research questions, articulating and the research design, identifying the study population and sampling procedures, the instrumentation to be used, and the procedures for collecting and analyzing the data. 


\section{Research Questions}

The following research questions guide this study:

1. Does length of participation in a Lifelong Learning Institute predict variance in individuals' inclinations to donate to the LLI or its hosting college/university?

2. Does an alumni relationship with the host college or university predict variance in individuals' inclinations to donate to the LLI or its host college or university?

3. Does the type of participation in a Lifelong Learning Institute predict variance in individuals' inclinations to donate to the LLI or its host college or university?

4. Does the frequency of participation in a Lifelong Learning Institute predict variance in individuals' inclinations to donate to the LLI or its host college or university?

5. Does level of satisfaction with a Lifelong Learning Institute predict variance in individuals' inclinations to donate to the LLI or its host college or university?

6. Does perceived commitment to an LLI predict variance in individuals' inclinations to donate to the LLI or its host college or university?

7. Does a perceived communal relationship with a LLI predict variance in individuals' inclinations to donate to the LLI or its host college or university?

\section{Research Design}

This study is anchored in a postpositivist approach. "Postpositivists," Cresswell tells us, "hold a deterministic philosophy in which causes (probably) determine effect or outcomes" (2014, p. 4). It relies upon the scientific method, beginning "with a theory [and then] collect[ing] data that either supports or refutes the theory" (p. 7). Specifically, this study relies on a quantitative, predictive nonexperimental design to "describe and measure the degree or association (or relationship) between two or more variables" (Creswell, 2014, p. 12); and to 
"generalize from a sample to a population so that inferences can be made about some characteristic, attitude, or behavior of this population" (p.146). The choice of a predictive nonexperimental study is premised on the idea that there are occasions when the researcher "does not have direct control of independent variables because their manifestations have already occurred or because they are inherently not manipulable. Inferences about relations among variables are made, without direct intervention, from concomitant variations of independent and dependent variables (Kerlinger, 1986, p. 348). This idea is supported by Johnson when he states, "nonexperimental quantitative research is an important area of research for educators because there are so many important but non-manipulable independent variables needing further study in the field of education" (Johnson, 2001 p. 5).

The selection of a predictive nonexperimental design is also supported by Johnson's article when he asks the following, "Did the researchers conduct the research so that they could predict or forecast some event or phenomenon in the future (without regard for cause and effect)? If the answer is "yes" (and there is no manipulation) then the term predictive nonexperimental research should be applied (Johnson, 2001 p. 6).

\section{Survey Research Method}

This study will use a survey research approach to collect quantitative data from participants in Osher Lifelong Learning Institutes (OLLI) about their behaviors and attitudes. Survey research is selected so that findings may be generalizable "from a sample to a population" (Creswell, 2014, p. 157). The survey will be cross-sectional, in that data will be collected from multiple participants in different locations at one point in time. Gay and Airasian state that, "a cross-sectional survey involves the collection of data from selected individuals in a single time period" (Gay \& Airasian, p. 279). Cross-sectional design is identified by Cresswell as 
one that will "examine current attitudes, beliefs, opinions, or practices" (2008, p. 389). He goes on to explain that "attitudes, beliefs, and opinions are ways in which individuals think about issues, whereas practices are their actual behaviors" (2008, pp.389-390). This survey will compare both the participants' beliefs and their behaviors.

\section{Study Population}

The population for this study includes all the individual older adults who are participants in OLLIs throughout the United States, called "members." Although there is a wide variety in LLIs, OLLI programs will be the single type examined in the study, delimiting for the attributes they offer, including the organization's national programmatic and structural guidelines for its member programs. Programmatically, OLLIs focus on a wide array of intellectually stimulating, non-credit, face-to-face (non-online) education offerings for older adults; engage members as volunteer leaders; and rely upon member feedback and evaluations. Structurally, OLLIs are housed at colleges and universities, have at least 500 enrolled members, and receive material contributions from their host institutions. These guidelines ensure some baseline commonality across OLLI programs, and lessen the degree of programmatic and structural variation found across LLIs broadly. "More than 154,000 people nationwide are members of Osher Lifelong Learning Institutes. Through satellite and partner locations, the 120 OLLIs offer courses and activities in 379 cities and towns throughout the U.S." (retrieved December 19, 2015, from nrc.northwestern.edu/2015/11/the-osher-lifelong-learning-institute-network/).

\section{Study Sample and Sampling Procedures}

The sample for the study will consist of the entirety of OLLI members. That is, all members from all OLLIs will be invited to participate. The researcher will employ cluster sampling (Vogt, 2007) to contact and invite study participants. Cluster sampling is an 
appropriate strategy when it is not practical or possible to sample directly from the population (Vogt, Gardner, Haeffle, 2012), such as "when the population is very large or spread out over a wide geographic area" (Gay \& Airasian, 2000, p. 129). This aptly describes OLLIs and their members, which are spread throughout the United States, which also differentiates them from other types of LLIs.

\section{Programs}

"In a multistage or clustering procedure," Creswell notes, "the researcher first identifies the clusters...obtains names of individuals within those clusters, and then samples within them" (2014, p. 158). The researcher will employ Creswell’s strategy. First, all OLLI programs (e.g. "the clusters") will be identified and contacted. The Bernard Osher Foundation maintains a publicly available list of all of the 119 OLLIs nationwide. Utilizing this list the researcher will contact each OLLI director, explain the purpose of the study, and seek his or her agreement to participate (Appendix A). The names of the participating OLLI programs and the college or university campuses on which they are located will be masked for the study, identified only by a number, a size indicator, and a public or private designation.

\section{Individuals}

The size of OLLI memberships varies from 500 individuals to several thousand. Specifically, the researcher will ask directors of each participating cluster to email an invitation to participate (Appendix B) to all its members which will contain an embedded link to the online survey (see Data Collection, below). Overall, approximately 150,000 people will be invited to participate. 


\section{Instrumentation}

The study will utilize an electronic survey instrument that includes 31 questions. The use of a survey is supported by Vogt who comments, "Often the only efficient way to obtain information about people is by asking them. This is especially true of 'subjective data'...such as their attitudes, beliefs, or values" (2007, p. 90). Since this study is exploring two subjective concepts - relationships and inclinations to donate - the most efficient way to obtain that information is to ask OLLI participants and because the study intends to sample the entire population of OLLI members, which number greater than 150,000, qualitative approaches would be impractical. It makes logistical sense to use a survey.

\section{Study Variables}

The survey questions (Appendix B) are divided into five sections based on question type. Section one contains eleven questions that ask for demographic information as well as the length and type of participation in OLLI. Sections two through four include twenty-one questions that ask about participant' satisfaction, commitment, and communal relationship with OLLI. Section five contains two questions that ask about participants' giving history to OLLI, the college or university that hosts it, or both.

The survey sections and questions on commitment, satisfaction, and communal relationship are adapted from Hon and Grunig's (1999) Guidelines for Measuring Relationships in Public Relations who "have found through their research that the outcomes of an organization's longer-term relationships with key constituencies can best be measured by focusing on six very precise elements or components of the relationships that exist" (p. 2). Although they have identified six elements, they assert that, "a shortened list of some of the items ... have been found to be valid measures of relationship outcomes" (p. 3). The researcher 
reviewed the six elements and identified three that are relevant to the study as those constructs seem most closely aligned with the OLLI experience: Satisfaction, Commitment, and Communal Relationships. Excluded from the study are Control Mutuality, Trust, and Exchange Relationship since those constructs do not align with the OLLI experience. Hon and Grunig's original questions and the survey questions adapted from them can be found in Appendix B.

Additionally, the researcher will be creating composite variables out of a cluster of survey items, and internal consistency measures will be evaluated using the Cronbach reliability analysis.

\section{Procedures}

The most significant rationale for utilizing an electronic survey is they are a cost effective approach to describe the characteristics of a large population of people (Wright, 2005), which may make the results statistically significant and thereby increase reliability of the study.

The use of an electronic survey has been debated due to concerns about sample selection, implementation, respondent lack of online experience, and accessibility (Evans and Mathur, 2005), but an April 2012 Pew Research Center survey indicates that $77 \%$ of American adults ages 50 (the age at which one can join OLLI) and older use the internet or email (Pew Research Center, 2014). As noted earlier, OLLI members value learning and are therefore more likely to be comfortable with these methods.

\section{Data Analysis Procedures}

After data collection the following analyses will be completed: (a) descriptive and frequency distributions for selected survey items and composite variables; (b) chi square analysis; (c) factor analysis to collapse items that seem to measure same concept or dimension and then to create composite scores for the dimensions in the data; (d) reliability analysis; (e) and 
regression analysis for predictive purposes. If the dependent variable is categorical, a discriminant function analysis will be used instead of the regression.

\section{Validity and Reliability}

Vogt (2007) observes that "validity means the relevance of the design or measure for the question being investigated, or the appropriateness of the design or measure for coming to

accurate conclusions" (p. 118). The research design for this study incorporates elements with the intent to ensure external validity (the generalizability of the results) and internal validity (the relevance of the results).

\section{External Validity}

The study's universal sampling approach is designed "to maximize external validity which refers to the degree to which the results drawn from the sample size can accurately be generalized beyond the subjects taking part in the study" (Vogt, p. 78). External validity is a concern when conducting predictive nonexperimental research. The primary concern is focused on interaction of selection and treatment; Creswell describes this as "because of the narrow characteristics of participants in the experiment, the researcher cannot generalize to individuals who do not have the characteristics of the participants) (2014, p. 165). Although this study cannot be generalized to members who participate in LLIs that are not OLLIs, it can be generalized to all OLLIs. The inclusion and invitation of all OLLI members throughout the United States provides external validity to the research.

\section{Internal Validity}

The researcher will use two strategies to ensure that the instrument used in the study is measuring the constructs for which it is intended. First, twenty-one questions in the survey instrument are existing measures of the constructs satisfaction, commitment, and communal 
relationship adapted from the work of Hon and Grunig (1999), as previously discussed. Only minor modifications in wording were made to the questions. Second, the entire survey instrument will be peer reviewed by a panel of experts, as recommended by Vogt (2007): experts' judgment, "is most often the only feasible way to assess content validity" (p.118). Following Vogt's recommendations, the researcher will identify three OLLI directors, ask them to review the survey instrument for content validity, and make any resultant revisions or improvements.

\section{Summary}

The purpose of this section was to identify and illuminate the quantitative approaches the researcher will utilize in pursuit of the research question responses. The researcher identified the questions and the statistical approaches to answer them and then constructed potential variables for a survey and explored concerns surrounding reliability and validity. In sum, the researcher has outlined a potential research topic and identified a gap in the available literature related to

\section{LLIs.}




\section{CHAPTER IV: FINDINGS}

\section{Overview}

This chapter presents the findings and analysis of the data collected through the administration of a survey provided to the members of eleven different Osher Lifelong Learning Institutes (OLLIs) throughout the United States. The purpose of this survey was to examine the relationship between an individual's involvement in Lifelong Learning Institutes and his or her propensity for philanthropic giving to the institute or its host college or university.

Organization-Public Relationships Theory, which originates in the field of public relations, provided a foundation by which to examine the relationships that LLIs (as organizations) develop with their public (member participants). Hon and Grunig's organizationpublic relationship framework (1999) help illuminate how the length, type, and frequency of participation, as well as the level satisfaction and feelings of community may relate to an LLI participant's inclination to donate.

This chapter has eight sections. The first section presents the data collection and timeline. The second identifies the demographic data collected and descriptive statistics created through the administration of the survey. In the third, the researcher resents a reliability analysis of the combined variables. The fourth section explores an analysis of each of the seven research questions identified in Chapter 3 - Methodology, and the fifth provides a factor analysis of the survey items. The six and seventh sections explore a one-way analysis of variance of the composite variables and a discriminant analysis of the composite variables, respectively. The eighth and final section summarizes the chapter. 


\section{Data Collection and Timeline}

The survey was administered to eleven Osher Lifelong Learning Institutes (OLLIs) in the United States during August and September of 2019. The 2017-18 OLLI membership of those institute is 14,082 . A total of 1,716 completed responses were received for an estimated response rate of $12.2 \%$. The survey was administered via email by each OLLI Director who provided a link to the survey on the common internet-based survey application Qualtrics. The survey was open for a total of six weeks, and directors were asked to send an initial request for participation and three reminders at their convenience during that time.

\section{Demographic Data and Descriptive Data}

A total of 1,716 surveys were completed by OLLI members. Members were asked to identify demographic information about themselves and the ways in which they participate in their OLLIs. The gender of the respondents was primarily female with 1,195 (69.6\%) of the survey respondents identifying as female, $511(29.85 \%)$ identifying as male, and $10(<1 \%)$ preferring not to respond to a question regarding gender. A significant majority, 1,624 (94.6\%), identified as white or Caucasian, with $38(2.2 \%)$ choosing to identify as other and $22(1.3 \%)$ as black or African American. Less than $1 \%$ of respondents identified as American Indian or Alaska Native, Asian, Hispanic or Latino, Native Hawaiian, or Other Pacific Islander respectively.

The majority of responders $(1,382$ or $80.2 \%)$ indicated they have been participating in OLLI for more than one year with only $19.5 \%$ participating for only one year or less (Table 4). 
Table 4

Length of Participation

\begin{tabular}{lcc}
\hline Number of Years & Members & $\%$ \\
\hline 0 - 1 years & 334 & 19.5 \\
2 - 4 years & 622 & 36.2 \\
5 - 9 years & 492 & 28.7 \\
$10+$ years & 268 & 15.6 \\
\hline
\end{tabular}

The majority of responders $(1,497$ or $87.2 \%)$ are not alumnus/alumna of the institution at which their OLLI is hosted (Table 5).

Table 5

Alumni Status

\begin{tabular}{lcc}
\hline Category & Members & $\%$ \\
\hline Not an alumnus / alumna. & 1,497 & 87.2 \\
Earned an undergraduate degree & 92 & 5.4 \\
Earned a graduate degree & 85 & 5.0 \\
Earned both an undergraduate and graduate degree here & 42 & 2.4 \\
\hline
\end{tabular}

Table 6 reveals that the majority members $(1,518$ or $88.5 \%)$ who responded to the survey have not served in a leadership role for their OLLI, such as serving on the governing board, executive committee, or leadership team.

Table 6

Leadership Roles

\begin{tabular}{lcc}
\hline Category & Members & $\%$ \\
\hline No, has not served in a leadership role & 1,518 & 88.5 \\
Yes, served in a leadership role & 190 & 11.1 \\
\hline
\end{tabular}

Although members may not have served in a leadership role, $35 \%$ or responding members have volunteered in some capacity for their OLLI (Table 7).

Table 7

Volunteered

\begin{tabular}{lcc}
\hline Category & Members & $\%$ \\
\hline No, has not volunteered & 1,110 & 64.7 \\
Yes, has volunteered & 598 & 34.8 \\
\hline
\end{tabular}


Table 8 denotes the frequency of participation in OLLI activities, programs, or meetings within the past twelve months of completing the survey: the majority $(58.1 \%)$ have participated at least seven times, $37.1 \%$ participated at least once, and only $4.5 \%$ did not participate at all.

Table 8

Participation in the Past 12 Months

\begin{tabular}{lcc}
\hline Category & Members & $\%$ \\
\hline No activities, programs, or meetings & 78 & 4.5 \\
1 to 6 times & 636 & 37.1 \\
7 to 12 times & 347 & 20.2 \\
13 to 24 times & 306 & 17.8 \\
25 to 36 times & 151 & 8.8 \\
More than 36 times & 194 & 11.3 \\
\hline
\end{tabular}

All seven research questions include the phrase "inclination to donate." Table 9 presents self-reported donation data for the OLLI members surveyed.

Table 9

Has Made One or More Financial Donations To

\begin{tabular}{lcc}
\hline Category & Members & $\%$ \\
\hline My OLLI & 393 & 22.9 \\
The Institution that hosts my OLLI & 165 & 9.6 \\
Both my OLLI and the institution that hosts it & 160 & 9.3 \\
Neither my OLLI nor the host institution & 988 & 57.6 \\
\hline
\end{tabular}

Less than half $(41.8 \%)$ of all OLLI members surveyed indicate that they have donated at least once to their OLLI, the institution that hosts their OLLI, or both their OLLI and the institution that hosts it. The majority of respondents $(57.6 \%)$ have not donated to either organization or institution.

\section{Reliability Analysis of Composite Variables}

The researcher reviewed the six elements of Hon and Grunig's original study (1999) and identified three that appear relevant to the research questions in the study. The three elements are Satisfaction, Commitment, and Communal Relationships; constructs which most closely align 
with the OLLI experience. Hon and Grunig's original questions (1999) and the survey questions adapted from them can be found in Appendix B. Additionally, the researcher created composite variables out of a cluster of survey items and applied internal consistency measures using the Cronbach reliability analysis.

The Satisfaction subscale was created by summing the responses to six items:

- Survey Question 9: I am happy with my OLLI.

- Survey Question 10: OLLI and people like me benefit from our shared relationship.

- Survey Question 11: Most people like me are happy in their interactions with OLLI.

- Survey Question 12: Generally speaking, I am pleased with the relationship that OLLI has established with people like me.

- Survey Question 13: Most people enjoy dealing with this OLLI.

- Survey Question 14: I feel people like me are important to OLLI.

The Commitment subscales was created by summing up the responses to seven items:

- Survey Question 15: I feel that OLLI is trying to maintain a long-term commitment to people like me.

- Survey Question 16: I can see that OLLI wants to maintain a relationship with people like me.

- Survey Question 17: There is a long-lasting bond between this OLLI and people like me.

- Survey Question 18: Compared to other organizations, I value my relationship with OLLI more.

- Survey Question 19: I would rather engage together in learning with this OLLI than not.

- Survey Question 20: I feel a sense of loyalty to my OLLI.

- Survey Question 21: I feel a sense of loyalty to the institution that hosts my OLLI.

The Communal Relationship subscale was created by summing the responses to eight items:

- Survey Question 22: OLLI enjoys giving others learning opportunities.

- Survey Question 23: OLLI is very concerned about the learning needs of people like me.

- Survey Question 24: OLLI is very concerned about the social needs of people like me.

- Survey Question 25: I feel that OLLI is committed to people who are interested in learning.

- Survey Question 26: I think that this OLLI succeeds by engaging people like me.

- Survey Question 27: OLLI helps people like me without expecting anything in return.

- Survey Question 28: I consider OLLI to be a particularly helpful organization.

- Survey Question 29: I believe the college or university that hosts my OLLI values the program. 
The Satisfaction subscale consisted of 6 items $(\alpha=.92)$, the Commitment subscale consisted of 7 items $(\alpha=.90)$, and the Communal Relationships subscale consisted of 8 items $(\alpha=.90)$. The composite variables were found to be highly reliable (Table 10).

Table 10

Instrument Subscales

\begin{tabular}{lcc}
\hline Subscales & No. Items & Cronbach's Alpha \\
\hline Satisfaction & 6 & .92 \\
Commitment & 7 & .90 \\
Communal Relationships & 8 & .90 \\
\hline
\end{tabular}

\section{Research Questions}

Seven research questions were identified for the study. Each research question is restated, an indication of whether or not a results analysis supported the question is provided, and the data and statistics to support the finding follows.

\section{Research Question 1: Length of Participation}

Does length of participation in an LLI predict variance in individuals' inclinations to donate to the LLI or its host college or university? There was a statistically significant relationship $\left(\chi_{2}(9, \mathrm{n}=1,706)=270.53, \mathrm{p}<0.001\right)$ between the number of years of participation and the inclination to donate. The most significant appears to be an inclination to donate to the OLLI, followed by an inclination to donate to both the OLLI and the host institution (Table 11).

Table 11

Inclination to Donate by Years of Participation

\begin{tabular}{lcccc}
\hline Years & Donate to OLLI & $\begin{array}{c}\text { Donate to Host } \\
\text { Institution }\end{array}$ & $\begin{array}{c}\text { Donate to Both } \\
\text { OLLI and Host } \\
\text { Institution }\end{array}$ & Donate to Neither \\
\hline $0-1$ years & $4.8 \%$ & $10.6 \%$ & $1.8 \%$ & $82.8 \%$ \\
$2-4$ years & $20.0 \%$ & $8.9 \%$ & $4.4 \%$ & $66.7 \%$ \\
$5-9$ years & $32.2 \%$ & $8.6 \%$ & $14.5 \%$ & $44.7 \%$ \\
$10+$ years & $35.8 \%$ & $12.3 \%$ & $20.9 \%$ & $31.0 \%$ \\
Mean & $23.0 \%$ & $9.7 \%$ & $9.4 \%$ & $57.9 \%$ \\
\hline
\end{tabular}




\section{Research Question 2: Alumni Relationship}

Does an alumni relationship with the host college or university predict variance in individuals' inclinations to donate to the LLI or its host college or university? There was a statistically significant relationship $\left(\chi_{2}(9, \mathrm{n}=1,706)=171.81, \mathrm{p}<0.001\right)$ between alumni status and the inclination to donate. The most significant appears to be an inclination to donate to the OLLI without being an Alumni followed by being both an Undergraduate Alumni and a Graduate Alumni (Table 12).

Table 12

Inclination to Donate by Alumni Status

\begin{tabular}{lcccc}
\hline Alumni Status & Donate to OLLI & $\begin{array}{c}\text { Donate to Host } \\
\text { Institution }\end{array}$ & $\begin{array}{c}\text { Donate to Both } \\
\text { OLLI and Host } \\
\text { Institution }\end{array}$ & $\begin{array}{c}\text { Donate to } \\
\text { Neither }\end{array}$ \\
\hline Not an Alumni & $24.5 \%$ & $6.9 \%$ & $7.6 \%$ & $60.9 \%$ \\
Undergraduate Alumni & $14.1 \%$ & $25.0 \%$ & $21.7 \%$ & $39.1 \%$ \\
$\begin{array}{l}\text { Graduate Alumni } \\
\begin{array}{l}\text { Both Undergraduate and } \\
\text { Graduate }\end{array}\end{array}$ & $14.1 \%$ & $24.7 \%$ & $22.4 \%$ & $38.8 \%$ \\
\hline
\end{tabular}

\section{Research Question 3: Type of Participation}

Does the type of participation in an LLI predict variance in individuals' inclinations to donate to the LLI or its host college or university? This research question is determined through two distinct questions from the survey: survey question 7 asks whether or not respondents currently serve or have ever served in a formal leadership role in their OLLI (such as member of its governing board, executive committee, or leadership team); survey question 8 asks whether or not respondents have ever volunteered for their OLLI in some capacity. There was a statistically significant relationship $(\chi 2(3, \mathrm{n}=1,698)=59.28, \mathrm{p}<0.001)$ between serving in a leadership role and the inclination to donate. The most significant appears to be an inclination to donate if the 
member has served as a leader. Approximately $64 \%$ who have served as leaders are inclined to donate whereas only $40 \%$ who have not served as leaders are inclined to donate (Table 13).

Table 13

Inclination to Donate by Leadership Service

\begin{tabular}{lcccc}
\hline Leadership Service & $\begin{array}{c}\text { Donate to } \\
\text { OLLI }\end{array}$ & $\begin{array}{c}\text { Donate to Host } \\
\text { Institution }\end{array}$ & $\begin{array}{c}\text { Donate to Both } \\
\text { OLL and Host } \\
\text { Institution }\end{array}$ & $\begin{array}{c}\text { Donate to } \\
\text { Neither }\end{array}$ \\
\hline $\begin{array}{l}\text { Served as a Leader } \\
\text { Have NOT Served as a }\end{array}$ & $31.9 \%$ & $10.1 \%$ & $21.8 \%$ & $36.2 \%$ \\
Leader & $22.0 \%$ & $9.7 \%$ & $7.8 \%$ & $60.5 \%$ \\
\hline
\end{tabular}

There was a statistically significant relationship $\left(\chi_{2}(3, \mathrm{n}=1,698)=102.55, \mathrm{p}<0.001\right)$

between serving as a volunteer and the inclination to donate. The most significant appears to be an inclination to donate if the member has served as a volunteer. Approximately 58\% who have served as a volunteer are inclined to donate whereas only $34 \%$ who have not served as a volunteer are inclined to donate (Table 14).

Table 14

Inclination to Donate by Volunteering

\begin{tabular}{lcccc}
\hline Volunteer & Donate to OLLI & $\begin{array}{c}\text { Donate to Host } \\
\text { Institution }\end{array}$ & $\begin{array}{c}\text { Donate to Both } \\
\text { OLLI and Host } \\
\text { Institution }\end{array}$ & Donate to Neither \\
\hline $\begin{array}{l}\text { Served as a } \\
\begin{array}{l}\text { Volunteer } \\
\text { Have NOT Served }\end{array}\end{array}$ & $32.0 \%$ & $10.4 \%$ & $15.1 \%$ & $42.4 \%$ \\
as a Volunteer & $18.1 \%$ & $9.2 \%$ & $6.4 \%$ & $66.3 \%$ \\
\hline
\end{tabular}

\section{Research Question 4: Frequency of Participation}

Does the frequency of participation in an LLI predict variance in individuals' inclinations to donate to the LLI or its host college or university? Survey question 6 asked respondents to indicate approximately how many times they have participated in OLLI activities, programs, or meetings within the past 12 months. There was a statistically significant relationship ( $\chi^{2}(15$, 
$\mathrm{n}=1,702)=128.59, \mathrm{p}<0.001)$ between frequency of participation and the inclination to donate. The most significant appears to be an inclination to donate to the OLLI as frequency of participation increases. Of those who participated 36 or more times within the past 12 months, $66 \%$ were inclined to donate (Table 15 ).

Table 15

Inclination to Donate by Frequency of Participation

\begin{tabular}{lcccc}
\hline $\begin{array}{l}\text { Frequency of } \\
\text { Participation in Past 12 } \\
\text { Months }\end{array}$ & Donate to OLLI & $\begin{array}{c}\text { Donate to Host } \\
\text { Institution }\end{array}$ & $\begin{array}{c}\text { Donate to Both } \\
\text { OLLI and Host } \\
\text { Institution }\end{array}$ & $\begin{array}{c}\text { Donate to } \\
\text { Neither }\end{array}$ \\
\hline Not Participated & $18.2 \%$ & $11.7 \%$ & $2.6 \%$ & $67.5 \%$ \\
$1-6$ Times & $15.0 \%$ & $12.7 \%$ & $6.2 \%$ & $66.1 \%$ \\
$7-12$ Times & $23.4 \%$ & $8.4 \%$ & $6.6 \%$ & $61.6 \%$ \\
$13-24$ Times & $24.9 \%$ & $7.5 \%$ & $12.8 \%$ & $54.8 \%$ \\
$25-36$ Times & $34.0 \%$ & $4.0 \%$ & $15.3 \%$ & $46.7 \%$ \\
More Than 36 Times & $38.5 \%$ & $9.4 \%$ & $17.7 \%$ & $34.4 \%$ \\
\hline
\end{tabular}

\section{Research Question 5: Level of Satisfaction}

Does level of satisfaction (a composite variable) with an LLI predict variance in individuals' inclinations to donate to the LLI or its host college or university? A chi-square test of independence was performed to examine the relationship between inclination to donate (giving behavior) and level of satisfaction. The relation between these variables was significant, $\left(\chi^{2}(20, \mathrm{n}=1,685)=86.51, \mathrm{p}<0.001\right)$ evidencing that the respondent's level of satisfaction (indicated by the composite score of how strongly they agreed or disagreed with statements on the Satisfaction subscale) with their OLLI predicted their likelihood of making a financial donation to their OLLI and/or its hosting institution.

\section{Research Question 6: Perceived Commitment}

Does perceived commitment (a composite variable) to an LLI predict variance in individuals' inclinations to donate to the LLI or its host college or university? A chi-square test of independence was performed to examine the relationship between inclination to donate and 
perceived commitment. The relation between these variables was significant, $(\chi 2(26, n=1,677)=$ 113.36, $\mathrm{p}<0.001$ ) evidencing that the respondent's level of perceived commitment (indicated by the composite score of how strongly they agreed or disagreed with statements on the Commitment subscale) to their OLLI predicted their likelihood of making a financial donation to their OLLI and/or its hosting institution.

\section{Research Question: 7 Perceived Communal Relationship}

Does a perceived communal relationship (a composite variable) with an LLI predict variance in individuals' inclinations to donate to the LLI or its host college or university? A chisquare test of independence was performed to examine the relationship between inclination to donate and perceived communal relationship. The relation between these variables was significant $\left(\chi^{2}(27, \mathrm{n}=1,675)=89.44, \mathrm{p}<0.001\right)$ evidencing that the respondent's level of perceived communal relationship (indicated by the composite score of how strongly they agreed or disagreed with statements on the Communal Relationship subscale) with their OLLI predicted their likelihood of making a financial donation to their OLLI and/or its host institution.

Significant relationships were found within each of the composite variables, and correlation at the 0.01 level (2-tailed) was also found among the composite variables (Table 16).

Table 16

Correlation of Composite Variables

\begin{tabular}{|c|c|c|c|c|c|}
\hline & & Donate & Satisfaction & Commitment & $\begin{array}{c}\text { Communal } \\
\text { Relationship }\end{array}$ \\
\hline \multirow{4}{*}{ Donate } & Pearson Correlation & 1 & $.185^{\star *}$ & $.215^{\star \star}$ & $.187^{\star \star}$ \\
\hline & Sig. (2-tailed) & & .000 & .000 & .000 \\
\hline & $\mathrm{N}$ & 1706 & 1685 & 1677 & 1675 \\
\hline & Pearson Correlation & $.185^{\star *}$ & 1 & $.845^{\star *}$ & $.812^{* \star}$ \\
\hline \multirow[t]{2}{*}{ Satisfaction } & Sig. (2-tailed) & .000 & & .000 & .000 \\
\hline & $\mathrm{N}$ & 1685 & 1694 & 1674 & 1667 \\
\hline \multirow{3}{*}{ Commitment } & Pearson Correlation & $.215^{\star \star}$ & $.845^{\star \star}$ & 1 & $.852^{\star \star}$ \\
\hline & Sig. (2-tailed) & .000 & .000 & & .000 \\
\hline & $\mathrm{N}$ & 1677 & 1674 & 1686 & 1664 \\
\hline \multirow{3}{*}{$\begin{array}{l}\text { Communal } \\
\text { Relationship }\end{array}$} & Pearson Correlation & $.187^{\star \star}$ & $.812^{\star \star}$ & $.852^{\star *}$ & 1 \\
\hline & Sig. (2-tailed) & .000 & .000 & .000 & \\
\hline & $\mathrm{N}$ & 1675 & 1667 & 1664 & 1682 \\
\hline
\end{tabular}




\section{Factor Analysis}

A factor analysis was completed on all survey items, and a rotated component matrix was created (Table 17) which indicates that the majority of the items aligned with Hon \& Gruig's Organization-Public Relationships Theory. The extraction method used was a Principal Component Analysis, utilizing a Varimax with Kaiser Normalization. The rotation converged in 26 iterations

Table 17

Rotated Component Matrix of Survey Items and Composite Variables

\begin{tabular}{|c|c|c|c|}
\hline Survey Item & Satisfaction & Commitment & $\begin{array}{l}\text { Communal } \\
\text { Relationship }\end{array}$ \\
\hline SQ 9. Happy with OLLI & .735 & & \\
\hline SQ 10. Benefit & .728 & & \\
\hline SQ 11. Happy in Interactions & .765 & & \\
\hline SQ 12. Pleased with Relationship & .791 & & \\
\hline SQ 13. Enjoy Dealing with OLLI & .707 & & \\
\hline SQ 14. Important to OLLI & .686 & & \\
\hline SQ 15.OLLI Maintains Commitment & .723 & & \\
\hline SQ 16. OLLI Maintains Relationship & .700 & & \\
\hline SQ 17. Bond with OLLI & .643 & & \\
\hline SQ 18. Value OLLI Relationship More than Other Orgs & & & .696 \\
\hline \multicolumn{4}{|l|}{ SQ 19. Desire to Engage Learning with OLLI } \\
\hline SQ 20. Sense of Loyalty to OLLI & & & .677 \\
\hline SQ 21. Sense of Loyalty to Host Institution & & & .712 \\
\hline SQ 22. OLLI Enjoys Giving Learning Opportunities & & .606 & \\
\hline SQ 23. OLLI Concerned with Learning Needs & & .611 & \\
\hline SQ 24. OLLI Concerned with Social Needs & & .572 & \\
\hline SQ 25. OLLI Committed to Interested Learners & & .607 & \\
\hline SQ 26. OLLI Succeeds by Engaging People & .630 & & \\
\hline SQ 27. OLLI Expects Nothing in Return & & .607 & \\
\hline SQ 28. OLLI As A Particularly Helpful Organization & & & \\
\hline SQ 29. Hosting College or University Values the OLLI & & .685 & \\
\hline
\end{tabular}

\section{One-Way Analysis of Variance Analysis}

The objective of the discriminant model was to establish whether a model existed that significantly increased the researcher's ability to accurately explain the patterning of discrimant function analysis weights. The discriminant analysis technique was found to be appropriate since the dependent variable, donating (Did Donate and Did NOT Donate), is a dichotomous variable 
(Klecka, 1980). The examined model included three predictors which provided the researcher with a model that was both substantively and statistically significant. The discriminant model aimed at maximizing the researcher's ability to correctly classify subjects on the dependent variable, defined as whether or not the subjects in the study fell in the donating group.

The first step in examining the discriminant model was to compare the group means on each of the independent variables (Table 18). The one-way analysis of variance (ANOVA) procedure was used to compare the two groups (Did Donate and Did NOT Donate). Of the three composite variables on which comparisons were made, the groups were found to be statistically different on all three variables.

As shown in Table 18, the variables on which the groups were significantly different were Satisfaction, Commitment, and Communal Relationship. This means that the discriminant function analysis model was statistically significant. Table 18 presents the one-way ANOVA results of the discriminating variable means, F-ratio, and probabilities associated with each variable by donation status.

Table 18

Group Means of Independent Variables

\begin{tabular}{lcccc}
\hline Discriminating Variable* & \multicolumn{2}{c}{ Group } & $F$-ratio & $p$ \\
\hline & $\begin{array}{c}\text { Did Donate } \\
\mathrm{n}=718\end{array}$ & $\begin{array}{c}\text { Did NOT Donate } \\
\mathrm{n}=988\end{array}$ & & \\
Satisfaction & 27.85 & 26.52 & 59.42 & $<.001$ \\
Commitment & 30.79 & 28.82 & 81.32 & $<.001$ \\
Communal Relationship & 35.90 & 34.17 & 60.75 & $<.001$ \\
\hline
\end{tabular}

*Descriptions of composite variables are provided in Appendix B

\section{Discriminant Analysis}

A discriminant function analysis was completed on the data: the participants were divided into two groups - Did Donate and Did NOT Donate for the Donate dependent variable. 
In the analysis, the factored three composite variables (Satisfaction, Commitment, and Communal Relationship) were used as an independent variable set. Table 19 identifies the dependent variable used in the discriminant function analysis, the most discriminating variables and their discriminant weights, and sample sizes for the groups.

Table 19

Unstandardized Discriminant Weights of the Instrument Composite Variables as Dependent Variable

\begin{tabular}{lcc}
\hline Independent variables & $\begin{array}{c}\text { Did Donate } \\
\mathrm{n}=718\end{array}$ & $\begin{array}{c}\text { Did NOT Donate } \\
\mathrm{n}=988\end{array}$ \\
\hline Satisfaction & 1.544 & 1.523 \\
Commitment & -.516 & -.615 \\
Communal Relationship & 1.240 & 1.252 \\
\hline
\end{tabular}

As can be seen in the results in Table 19, the most important independent variables contributing to the linear discriminant functions predicting group membership for the Donate variable in descending order were Satisfaction, Communal Relationship, and Commitment. Of interest as well are the weight and direction of two of the composite variables: (positive) Satisfaction and Communal Relationship.

The results of the discriminant analysis show that a substantively and statistically significant model exists that enhanced the researcher's ability to accurately predict participant classification into Did Donate or Did NOT Donate groups based on Satisfaction, Commitment and Communal Relationship, and composite variables. All the model variables made significant differences between the two groups, but since the dependent variable consisted of two levels, only one discriminant function could be generated. The discriminant function analysis reveals significant $(p<0.001)$ group differences for each independent variable. The canonical correlation $(r=0.217)$ indicates the function is weakly related to the levels in the dependent variable. Squaring this value produces the effect size, which reveals that $5 \%$ of function variance is 
accounted for by the dependent variable. The overall Wilk's lambda was significant, $Л=0.953$, $\left.\chi^{2}(3, n=1716)=79.57, p<0.001\right)$, and indicates that the function of predictors significantly differentiated between the two groups. Evaluation of the standardized discriminant function coefficients reveals that Commitment (0.964) had the highest loading, followed by Satisfaction (0.161), and Communal Relationship (-0.121).

Classification results reveal that $69 \%$ were correctly classified into the Did Donate group while $52 \%$ were classified into the Did NOT Donate group. The means of the discriminant functions are consistent with the aforementioned results. Did Donate had a function mean of 0.260 while Did NOT Donate had a mean of -0.191 suggesting that participants with-high scores on Satisfaction, Commitment and Communal Relationship composite variables are likely to be classified donors. In considering the patterning of discriminant weights for the various independent variables, weights were slightly higher for the Did Donate group than for the Did NOT Donate group.

\section{Summary}

Chapter 4 - Findings presented the results of the myriad demographic and statistical measures used to confirm the relationships and correlations between a variety of variables and composite variables identified for the purposes of this study. The data collection process and timeline were identified; the demographic data and descriptive statistics were provided; a reliability analysis of the composite variables was offered; the seven research questions were investigated; and a factor analysis of all the survey items was presented. Finally, all null hypotheses were rejected, and the variables of interest were evidenced as statistically significant predictors of inclination to donate. 


\section{CHAPTER V: CONCLUSIONS AND IMPLICATIONS}

\section{Overview}

The purpose of this study was to examine the relationship between an individual's involvement in Osher Lifelong Learning Institutes (OLLIs) and his or her propensity for philanthropic giving to the institute or its host college or university using a quantitative survey focused on demographic, participation behaviors, and composite variables. The data analysis focused on the inclinations of members to donate in the context of the demographic data, participation behaviors, and composite variables. Background, limitations, discussion of findings, implications, recommendations, and areas for future study are detailed in the following sections.

\section{Background}

The impact of Lifelong Learning Institutes on individual members has been explored through both qualitative and quantitative studies (Brady, Carlisle, \& Neidy, 2013; Hansen, Brady, \& Thaxton, 2016; Kim \& Merriam, 2004; Lamb \& Brady, 2005; Martin, 2002; and Talmage et.al, 2019), but the available literature related to the giving relationship between the LLI provider and the LLI member is somewhat sparse and may provide an opportunity to hosting institutions.

The findings presented as part of this research study illustrate the relationships that OLLI members develop with their hosting institutions and can inform those administrators to improve philanthropic giving. The researcher examined several variables using quantitative statistical methods and found that length of participation, type of participation, frequency of participation, level of satisfaction, perceptions of commitment, and perceptions of communal relationship have a positive impact on the inclination to give, regardless of alumni status. The data from this 
survey suggests more intentional actions by hosting institution administrators and OLLI directors may increase members' inclinations to donate.

The seven research questions of the study were organized around three areas: alumni status; length, type, and frequency of participation; and three composite variables related to strength of the relationship. For each research question the null hypothesis was rejected.

\section{Limitations}

The data successfully rejected the null hypotheses for each research question, but there are limitations to the study. First, the validity and reliability of this study are only applicable to Osher Lifelong Learning Institutes (OLLIs), not other types of Lifelong Learning Institutes (LLIs) as identified in Chapter 2 - Literature Review. Second, the response rate for the study can only be estimated as the method of survey administration (with surveys being forwarded by OLLI program directors) obscured any distinction between non-respondents and unsuccessful survey delivery. However, this was an acceptable limitation given that response rates to online surveys are generally lower than paper-based surveys (Nulty, 2008); older adults tend to have lower response rates to online surveys than younger participants (Palonen, Kaunonen, \& AstedtKurki, 2016), yet older adults are more inclined to participate in a survey if they know the person requesting participation (Edelman et al., 2013). Regardless of this concern, the email approach was the most practical given the resources available and enabled the researcher to contact a larger sample pool than could have been contacted using other methods that require more time or resources. Regardless of this concern, the email approach was the most practicable given the resources available, and enabled the researcher to contact a larger sample pool than could have been contacted using other methods that consume more time or financial resources, Third, while there were enough responses to run accurate statistical tests on the respondents, it is not possible 
to determine the representativeness of the resulting sample or the potential for any non-response bias since that data is not available to the researcher.

\section{Discussion of Findings}

The first research question examined the relationship between length of participation in an OLLI and philanthropic giving to the OLLI or its host college or university.

Major Finding RQ1: Does length of participation in an LLI predict variance in individuals' inclinations to donate to the LLI or its host college or university? There is a statistically significant positive relationship $(\chi 2(9, \mathrm{n}=1,706)=270.53, \mathrm{p}<0.001)$ between the number of years of participation and the inclination to donate. The most significant appears to be an inclination to donate to the OLLI, followed by an inclination to donate to both the OLLI and the host institution. This relationship can be expected given that a member who is more familiar with an organization is more likely to donate to that organization and that the length of the relationship may influence the inclination to give.

The second research question investigated the relationship between alumni status and philanthropic giving to the OLLI or its host college or university.

The second research question investigated the relationship between alumni status and philanthropic giving to the OLLI or its host college or university.

Major Finding RQ2: Does an alumni relationship with the host college or university predict variance in individuals' inclinations to donate to the LLI or its host college or university? There was a statistically significant relationship $(\chi 2(9, \mathrm{n}=1,706)=171.81, \mathrm{p}<0.001)$ between alumni status and the inclination to donate. OLLI members who are not alumni of the host institution are more likely to donate only to their OLLI than to both their OLLI and the host institution or the host institution alone. In contrast, OLLI members who were undergraduate 
and/or graduate alumni of the host institution were more likely to give to either the host institution or both the OLLI and the host institution, than to their OLLI alone. This distinction may be attributable to the diffusion of member attention and resources. OLLI members who are not alumni of the host intuition may not necessarily feel a relationship or commitment to the host institution and may be less likely to receive communications and fundraising outreach from that institution. In contrast, members who are also alumni may feel greater a relationship and commitment to the host institution and therefore may be more likely to receive ongoing communications and fundraising outreach from that institution. Given that attention and resources are finite, the diffusion of attention may lead to the diffusion of resources.

The third research question explored the relationship between type of participation in an OLLI and philanthropic giving to donate to the OLLI or its host college or university. Major Finding RQ3: Does the type of participation in an LLI predict variance in individuals' inclinations to donate to the LLI or its host college or university? This research question was determined through two distinct questions: survey question 7 asks whether or not respondents currently serve or have ever served in a formal leadership role in their OLLI (such as member of its governing board, executive committee, or leadership team); survey question 8 asks whether or not respondents have ever volunteered for their OLLI in some capacity. There was a statistically significant relationship $(\chi 2(3, \mathrm{n}=1,698)=59.28, \mathrm{p}<0.001)$ between serving in a formal leadership role and the inclination to donate. Approximately $64 \%$ of members who have served in such roles are inclined to donate whereas only $40 \%$ of OLLI members who have not served as a leader are inclined to donate.

There was also a statistically significant and positive relationship $(\chi 2(3, n=1,698)=$ $102.55, \mathrm{p}<0.001)$ between serving as a volunteer and the inclination to donate. Approximately 
$58 \%$ of members who have served as a volunteer are inclined to donate whereas only $34 \%$ of members who have not served are inclined to donate. Much like RQ1, these two relationships are expected given that a member who is more familiar with an organization is more likely to donate and that holding a leadership role or volunteering breeds familiarity, and may influence the inclination to give.

The fourth research question examined the relationship between frequency of participation in an OLLI and philanthropic giving to the OLLI or its host college or university. Major Finding RQ4: Does the frequency of participation in an LLI predict variance in individuals' inclinations to donate to the LLI or its host college or university? There was a statistically significant, positive relationship $(\chi 2(15, \mathrm{n}=1,702)=128.59, \mathrm{p}<0.001)$ between frequency of participation and the inclination to donate. Of those respondents who participated in OLLI events and activities 36 or more times within the past 12 months, $66 \%$ were inclined to donate. Much like RQ1 and RQ3, this relationship is expected given that a member who is more familiar with an organization is more likely to donate to that organization; and that frequent participation increases familiarity with the organization and its needs, and thereby an inclination to donate.

The fifth, sixth, and seventh research questions utilized composite variables adapted from Hon and Grunig's (1999) study and Broom, Casey, and Ritchey's (2000) Organization-Public Relationships Theory which explored how elements of satisfaction, perceived commitment, and perceived communal relationship may influence a member to donate to the organization.

Major Finding RQ5: Does level of satisfaction (a composite variable) with an LLI predict variance in individuals' inclinations to donate to the LLI or its host college or university? The relationship between these variables was significant, $(\chi 2(20, \mathrm{n}=1,685)=86.51, \mathrm{p}<0.001)$ 
evidencing that the respondent's level of satisfaction (indicated by the composite score of how strongly they agreed or disagreed with statements on the Satisfaction subscale) with their OLLI predicted their likelihood of making a financial donation to their OLLI and/or its host institution.

Major Finding RQ6: Does perceived commitment (a composite variable) to an LLI predict variance in individuals' inclinations to donate to the LLI or its host college or university? A chi-square test of independence was performed to examine the relationship between inclination to donate and perceived commitment. The relation between these variables was significant $\left(\chi^{2}(26, \mathrm{n}=1,677)=113.36, \mathrm{p}<0.001\right)$ evidencing that the respondent's level of perceived commitment (indicated by the composite score of how strongly they agreed or disagreed with statements on the Commitment subscale) to their OLLI predicted their likelihood of making a financial donation to their OLLI and/or its host institution.

Major Finding RQ7: Does a perceived communal relationship (a composite variable) with an LLI predict variance in individuals' inclinations to donate to the LLI or its host college or university? A chi-square test of independence was performed to examine the relationship between inclination to donate and perceived communal relationship. The relation between these variables was significant $\left(\chi^{2}(27, \mathrm{n}=1,675)=89.44, \mathrm{p}<0.001\right)$ evidencing that the respondent's level of perceived communal relationship (indicated by the composite score of how strongly they agreed or disagreed with statements on the Communal Relationship subscale) with their OLLI predicted their likelihood of making a financial donation to their OLLI and/or its host institution.

Significant relationships were found within each of the composite variables, and correlation at the 0.01 level (2-tailed) was also found among the composite variables. While the significance is somewhat weaker within the composite variables than within the variables associated with alumni status and participation, they are still strong enough to support the 
conclusions drawn from Broom, Casey, and Ritchey's (2000) Organization-Public Relationships Theory which asserts that focusing on satisfaction, commitment, and communal relationship can influence the positive feelings a member has concerning an organization and thereby increase their inclination to donate.

\section{Recommendations}

The literature about LLIs and specifically OLLIs continues to emerge out of academe. These programs for older engaged adults are typically hosted at colleges and universities throughout the United States. The learning and social benefits to participant/members have been explored through both qualitative and quantitative means, but the potential financial benefits to the programs and their host institutions have not been explored as deeply. This study serves as a foundation to explore that potentiality.

Data from the existing literature and this study suggest that increasing the engagement of members may increase their propensity to donate to the programs or the host institutions. The survey results of this study were informative to understanding the giving behaviors of OLLI members as they relate to numerous aspects of relationships and types of engagement. However, the data also suggests that a pre-existing alumni relationship is not a strong indicator of an inclination to donate. Based on the findings from the study, in order to influence an individual's inclination to donate it is necessary to provide engagement opportunities such as volunteering or leadership, offer more opportunities for participation, and build on the relationship between the organization and the member. It is clear that opportunities exist to influence the donating behavior of OLLI members, and OLLI program directors are in the position to create and coordinate these opportunities. Below are the following recommendations that emerged based on the findings in this study: 
1. Institutions of higher education should recognize the potential of OLLI members to donate and provide resources to foster the giving relationship.

2. Institutions of higher education should consider that engaged OLLI members are inclined to donate regardless of alumni relationship and include them in institution-wide fundraising efforts.

3. OLLI program directors, working in cooperation with their programming committees, should increase the variety of programming options in order to increase the frequency of participation.

4. OLLI program directors, working in cooperation with their leadership committees, should develop additional leadership opportunities in order to increase the number of members who consider themselves leaders of the organization.

5. OLLI program directors, working in cooperation with their leadership committees, should develop term limits for leadership roles in order to increase the number of members who consider themselves leaders of the organization.

6. OLLI program directors, working in cooperation with their leadership committees, should identify and implement various volunteer roles - outside of leadership roles - in order to increase the number of members who consider themselves more connected to the organization.

7. OLLI program directors, working in cooperation with their leadership committees, should engage in analysis and strategic planning related to the concept of satisfaction with the program. 
8. OLLI program directors, working in cooperation with their leadership committees should engage in analysis and strategic planning related to the concept of commitment to the program.

9. OLLI program directors, working in cooperation with their leadership committees, should engage in analysis and strategic planning related to the concept of sense of communal relationship with the program.

10. OLLI program directors, working in cooperation with OLLI stakeholders, should review and discuss the results of this study with each other in order to inform strategic planning efforts.

These recommendations will be shared with the OLLI program directors whose members participated in the study

\section{Areas for Future Study}

It is the responsibility of all stakeholders (OLLI directors, staff, volunteer leadership, and volunteers) to assure that OLLIs exist as a learning option for older adults. In order to make research-based decisions, studies such as this need to be expanded upon to provide direction and planning for improvements. Suggestions for prospective studies include the following:

1. Repeat this study, taking a multi-method approach to survey administration (e.g., online but also with mail, phone, or in-person options) since a study of differences in survey response rates among older adults have suggested that "the best way to ensure high response rates involving people aged 60 or older is to collect data in the presence of the researcher; response rates are lowest in posted surveys and settings where the researcher is not present when data are collected" (Palonen, Kaunonen, \& Astedt-Kurki, 2016). 
2. Repeat this study, but obtain preliminary descriptive information about the sample population, to the extent possible, so that differences in responders vs. non-responders may be examined.

3. Use a qualitative or mixed methods approach to examine the same subject to yield findings that were not possible in a quantitative study. For example, interviews of OLLI members, program directors, and/or institutional leadership may provide valuable understanding into the underlying dynamics of how and why phenomena such as participation, commitment, and satisfaction relate to philanthropic giving, and what strategies may work well for increasing these behaviors and attitudes among OLLI members.

4. Engage in focus group research that allows the researcher to discover the narrative connection between leadership and volunteering and an inclination to donate.

5. Analyze the qualitative responses from this study's survey question, "I have not made a financial donation (outside of membership or fees) to my OLLI nor the host institution because:" to explore members' rationales for not donating.

6. Explore the data from this survey more deeply as the data set may yield insights regarding relationships between gender, ethnicity, and philanthropic behavior that may help target fundraising efforts.

\section{Summary}

The purpose of this study was to examine the relationship between an individual's involvement in OLLIs and his or her propensity for philanthropic giving to the institute or its host college or university utilizing quantitative research methodologies which focused on the relationships that LLIs (as organizations) develop with their public (member participants). Hon and Grunig's organization-public relationship framework (1999) helped illuminate how the 
length, type, and frequency of participation, as well as the level satisfaction, commitment, and feelings of community may relate to an LLI participant's inclination to donate. Improving the inclination to donate, and thereby increasing resources for OLLIs at colleges and universities throughout the United States, may help meet the growing demand among older adults for engaged learning activities. Utilizing survey research methods, this study addressed whether an inclination to donate was correlated with the length, type, and frequency of participation, as well as the level of satisfaction, commitment, and feelings of community.

The research found that length, type, and frequency of participation, as well as the level of satisfaction, commitment, and feelings of community were positive predictors of an OLLI member's inclination to donate. Alumni status, however, was not necessarily a good predictor. Based on these findings, ten recommendations were provided to assist OLLIs with increasing behaviors and relationships that are associated with an increased inclinations of philanthropic giving among OLLI members.

Specific recommendations for future studies include an analysis of qualitative data set collected from this survey to explore barriers to donating. Additionally, analyzing survey results by gender and ethnicity may provide more insight into any potential interactions between philanthropic giving, individual demographics, and participation, satisfaction, commitment, and feelings of community. The results of these suggested studies may help inform specific direction for strategic initiatives.

This study adds to the literature about older adult learning, LLIs, OLLIs, and philanthropic giving. It also provides direction for future strategic initiatives of existing OLLIs to preserve their survival in an increasingly under-resourced higher education environment. 


\section{REFERENCES}

A brief overview of the LLI movement. (n.d.). [Webpage]. Retrieved from http://www.elderhostel.org/ein/overview.asp

American Council on Education. (2008). Mapping new directions: Higher education for older adults. Washington, DC: American Council on Education.

Anderson, J. E. (1955). Teaching and learning. In W. Donahue, (Ed.). Education for later maturity: A handbook. (The Adult Education Association of the United States of America). New York, NY: Whiteside, Inc. and William Morrow \& Company, Inc.

Bastable, S. R., Gramet, P., Jacobs, K., \& Sopczyk, D. (2010). Health professional as educator: Principles of teaching and learning. New York, NY: Jones \& Bartlett Learning.

Blazey, M. L. (1992). Starting your own learning-in-retirement program. In Fischer, R. B., Blazey, M. L., \& Lipman, H. T. (Eds.). Students of the third age. New York, NY: American Council on Education and MacMillan Publishing Company.

Bolman, L. G., \& Deal, T. E. (2003). Reframing organizations: Artistry, choice, and leadership ( $3^{\text {rd }}$ ed.). San Francisco, CA: Jossey-Bass.

Bowen, H. R. (1980). The costs of higher education: How much do colleges and universities spend per student and how much should they spend? San Francisco, CA: Jossey-Bass.

Brady, E. M., Cardale, A., \& Neidy, J. C. (2013). The quest for community in Osher lifelong learning institutes. Educational Gerontology, 39, 627-639.

doi:10.1080/03601277.2012.734147 
Broom, G. M., Casey, S., \& Ritchey, J. (2000). Concept and theory of organization-public relationships. In J. A. Ledingham, \& S. D. Bruning, (Eds.). Public relations as relationship management (pp.3-22). Mahwah, NJ: Lawrence Erlbaum Associates, Inc.

Bryson, J. (2004). Strategic planning for public and nonprofit organizations. A guide to strengthening and sustaining organizational achievement (3rd ed.). San Francisco, CA: Jossey-Bass.

Clark, B. R. (1958). The marginality of adult education: No. 20: Notes and Essays on Education of Adults. Brookline, MA: Center for the Study of Liberal Education for Adults.

Clark, F., Fochs Heller, A., Rafman, C., \& Walker, J. (1997). Peer learning: A popular model for seniors' education. Educational Gerontology, 23, 751-762.

Coughlan, M., Cronin, P., \& Ryan, F. (2009). Survey research: Process and limitations. International Journal of Therapy \& Rehabilitation, 16(1), 9-15.

Creswell, J. W. (2014). Research design: Qualitative, quantitative, and mixed methods approaches, $\left(4^{\text {th }}\right.$ ed.). Thousand Oaks, CA: Sage.

Deakin Crick, R., \& Wilson, K. (2005). Being a learner: A virtue for the $21^{\text {st }}$ century. British Journal of Educational Studies, 53(3), 359-374. doi:10.1891/0198979428111

DiMaggio, P. J., \& Powell, W. W. (1983). The iron-cage revisited: Institutional isomorphism and collective rationality in organizational fields. American Sociological Review, 48(2), 147160.

Donahue, W. T. (1955). Education for later maturity: A handbook. New York, NY. Whiteside, Inc., William Morrow \& Company, Inc., and The Adult Education Association of the United States of America. 
Drath, W. (2001). The deep blue sea. Rethinking the source of leadership. San Francisco, CA: Jossey Bass.

Edeleman, L. S., Yang, R., Guymon, M., \& Olson, L. (2013). Survey methods and response rates among rural community dwelling older adults. Nursing Research, 62(4), 286-291. doi: 10.1097/NNR.0b013e3182987b32

Eisen, M. J. (2005). Shifts in the landscape of learning. In M.A. Wolf, (Ed.). Adulthood: New terrain. New Directions for Adult and Continuing Education, (2005)108, 15-26. San Francisco, CA: Jossey-Bass.

Evans, J. R., \& Mathur, A. (2005). The value of online surveys. Internet Research, 15(2), 195 219. https://doi.org/10.1108/10662240510590360

Find a Lifelong Learning Institute. (n.d.). [Webpage]. Retrieved from http://www.elderhostel.org/Ein/map_usca.asp

Fischer, R. B., Blazey, M. L., \& Lipman, H. T. (Eds.). (1992). Students of the third age. New York, NY: American Council on Education and MacMillan Publishing Company.

Formosa, M. (2002). Critical gerogogy: Developing practical possibilities for critical educational gerontology. Education and Ageing 17(1), 73-85.

Gay, L. R., \& Airasian, P. W. (2000). Educational research: Competencies for analysis and application. Upper Saddle River, N.J.: Merrill.

Glendenning, F. (2001). Education for older adults. International Journal of Lifelong Education, 20(1), 63-70. doi:10.1080/02601370010008255

Goldstein, L. (2005). College \& university budgeting: An introduction for faculty and academic administrators (3rd ed.). Washington, DC: National Association of College \& University Business Officers. 
Greenleaf, R. K. (2002, 25th Anniversary Edition). Servant leadership. New York, NY: Paulist Press.

Hansen, R. J., Brady, E. M., \& Thaxton, S. P. (2016). Demographic and behavioral characteristics of Osher lifelong learning institute members. Journal of Continuing Higher Education, 64, 42-50. doi:10.1080/07377363.2016.1131541

Hanson, A. (1996). The search for separate theories of adult learning: Does anyone really need andragogy? In R. Edwards, A. Hanson, \& P. Raggatt (Eds.), Boundaries of adult learning: Adult learners, education and training, Vol. 1 (p. 107). London, England: Routledge.

Hebestreit, L. K. (2006). An evaluation of the role of the university of the third age in the provision of lifelong learning. Unpublished doctoral dissertation, University of South Africa.

Heifetz, R. A. (1994). Leadership without easy answers. Cambridge, MA: Harvard University Press.

Hiemstra, R. (1998). From whence have we come? The first twenty-five years of educational gerontology. In J. S. Fischer \& M. A. Wolf (Eds.), Using Learning to Meet the Challenges of Older Adulthood. New Directions for Adult and Continuing Education, No. 77, Spring 1998 (pp. 5-14). San Franciso, CA: Jossey-Bass.

Hon, L. C., \& Grunig, J. E. (1999). Guidelines for Measuring Relationships in Public Relations(Tech.). Institute for Public Relations. doi:https://www.instituteforpr.org/wpcontent/uploads/Guidelines_Measuring_Relationships.pdf

Jarvis, P. (2001). Learning in later life: An introduction for educators and carers. London, England: Kogan Page. 
Jo, S., Hon, L. C., \& Brunner, B. R. (2004). Organization-public relationships: Measurement validation in a university setting. Journal of Communication Management, 9(1), 14-27.

Johnson, B. (2001). Toward a New Classification of Nonexperimental Quantitative Research. Educational Researcher, 30(2), 3-13. https://doi.org/10.3102/0013189x030002003

Kim, A., \& Merriam, S. B. (2004). Motivations for Learning among older adults in a learning in retirement institute. Educational Gerontology, 30(6), 441-455. doi:10.1080/03601270490445069

Kinsella, K., \& He, W. (2009). U.S. Census Bureau, international population reports, p95/09-1, an aging world: 2008, U.S. Government Printing Office, Washington, DC.

Klecka, W. R. (1980). Discriminant analysis, Sage University Paper Series on Quantitative Applications in the Social Sciences, 07-019. Beverly Hills, CA: Sage Publications.

Knowles, M. S., Holton, E.F., \& Swanson, R. A. (1998). The adult learner, $5^{\text {th }}$ edition. Woburn, MA: Butterworth-Heinemann.

Knowles, M. S., Holton, E. F., \& Swanson, R. A. (2005). The Adult Learner, $6^{\text {th }}$ edition. Boston, MA. Elsevier.

Kressley, K. M., \& Huebschmann, M. (2002). The 21st century campus: Gerontological perspectives. Educational Gerontology, 28, 835-851.

Lamb, R., \& Brady, E. M. (2005). Participation in lifelong learning institutes: What turns members on? Educational Gerontology, 31, 207-224.

Lamdin, L. S. (1997). Elderlearning: A new frontier in an aging society. Phoenix, AZ: The Oryx Press.

Lightfoot, Lawrence S. (2009). The third chapter: Passion, risk, and adventure in the 25 years after 50. New York, NY: Sarah Crichton Books. 
Lemieux, A., \& Martinez, M. S. (2000). Gerontagogy beyond words: a reality. Educational Gerontology, 26(5), 475-498.

Lifelong learning institutes \& Road scholar. (n.d.) [Webpage]. Retrieved from http://www.elderhostel.org/Ein/map_usca.asp

Linnehan, M., \& Naturale, C. (1998). The joy of learning in retirement. Journal of Physical Education, Recreation \& Dance, 69(3), 32-33.

Lum, L. (2005). From shakespeare to sports. Diverse Issues in Higher Education (22)17, 26-28.

Manheimer, R. J. (2008). Lifelong learning in aging societies: Emerging paradigms. Annual Review of Gerontology and Geriatrics, 28, 111-127.

Manheimer, R. J., Snodgrass, D. D., \& Moskow-McKenzie, D. (1995). Older adult education: A guide to research, programs, and policies. Westport, CT: Greenwood Press.

Martin, C. L. (2002). Learning in retirement institutes: The impact on the lives of older adults. Unpublished doctoral dissertation. University of Massachusetts, Amherst.

Martin, D. L., \& Lyday, J. (1997). Feelings of loyalty among members of learning-in-retirement programs. Educational Gerontology, 27, 315-327.

McGrath, V. (2009). Reviewing the evidence on how adult students learn: An examination of Knowles' model of andragogy. Adult Learner: The Irish Journal of Adult and Community Education, 99-110.

Merriam, S. B. (2001). Andragogy and self-directed learning. In S. B. Merriam (Ed.), The New Update on Adult Learning Theory: New Directions for Adult and Continuing Education, No. 89, Spring 2001 (pp. 3-13). San Francisco, CA: Jossey-Bass.

Merriam, S. B., \& Brockett, R. G. (2007). The profession and practice of adult education: An introduction. San Francisco, CA: Jossey-Bass. 
Merriam, S. B., Caffarella, R., \& Baumgartner, L. (2007). Learning in adulthood: A comprehensive guide ( ${ }^{\text {rd }}$ ed.). San Francisco, CA: Jossey-Bass.

Merz Nordstrom, N. (n.d.). The learning in retirement movement in North America. Retrieved April 09, 2010, from http://www.exploritas.org/ein/learning_na.asp

Miller, P. A. (1992). Introduction: negotiating the retirement rite. In R. B. Fischer, M. L. Blazey, \& H. T. Lipman, (Eds.). Students of the third age (pp.1-9). New York, NY: American Council on Education and MacMillan Publishing Company.

Mills, P. K., \& Margulies, N. (1980). Toward a core typology of service organizations. Academy of Management Review 5(1), 255-265.

Mintzberg, H. (1985). The organization as political arena. Journal of Managerial Studies, 22(2), $133-154$

Morgan, D. (1998, Spring). Introduction: The aging of the baby boom. Generations, 22(1), 5.

National Institute on Aging. (2007). Why population aging matters: A global perspective.

Retrieved June 14, 2009, from http://www.nia.nih.gov/NR/rdonlyres/9E91407E-CFE84903-9875-D5AA75BD1D50/0/WPAM.pdf

Nulty, D. D. (2008). The adequacy of response rates to online and paper surveys: what can be done?, Assessment \& Evaluation in Higher Education, 33(3), 301-314, doi: 10.1080/02602930701293231

Palonen, M., Kaunonen, M., \& Astedt-Kurki, P. (2016). Exploring how to increase response rates to surveys of older people. Nurse Researcher, 23-5, 15-19. 5p. doi: $10.7748 / \mathrm{nr} .23 .5 .15 . \mathrm{s} 4$

Peterson, D. A. (1983). Facilitating education for older learners. San Franciso, CA: JosseyBass. 
Peterson, D. A. (1985). Toward a definition of educational gerontology. In R. H. Sherron \& D. B. Lumsden (Eds.), Introduction to educational gerontology. Washington, DC: Hemisphere Publishing Corporation.

Pew Research Center, (2014). Older Adults and Technology Use. Available at: http://www.pewinternet.org/2014/04/03/older-adults-and-technology-use/

Rost, J. C. (1991). Leadership for the twenty-first century. Westport, CT: Praeger.

Rowley, D. J., Lujan, H. D., \& Dolence, M. G. (1997). Strategic change in colleges and universities: Planning to survive and prosper. San Francisco, CA: Jossey Bass.

Senge, P. M. (1990). The fifth discipline. New York, NY: Doubleday.

Senge, P., Scharmer, C. O., Jaworski, J., \& Flowers, B. S. (2005). Presence: An exploration of profound change in people, organizations, and society. New York, NY: CurrencyDoubleday.

Simon, M. K. (2011). Dissertation and scholarly research: Recipes for success (2011 Ed.). Seattle, WA: Dissertation Success, LLC.

Swindell, R., \& Thompson, J. (1995). An international perspective of the university of the third age. Retrieved April 19, 2010, from http://worldu3a.org/resources/u3a-worldwide.htm

Talmage, C. A., Hansen, R. J., Knopf, R. C., Thaxton, S. P., McTague, R., \& Moore, D. B. (2019). Unleashing the value of lifelong learning institutes: research and practice insights from a national survey of osher lifelong learning institutes Adult Education Quarterly, 69-3, 184-206. doi: 10.1177/2F0741713619834651

The Bernard Osher Foundation Lifelong Learning Institutes. (n.d.). [Webpage]. Retrieved April 23, 2010, from http://www.osherfoundation.org/index.php?olli 
The Changing Demographic Profile of the United States. (2006) Congressional Research

Service. Retrieved April 23, 2010, from: http://www.fas.org/sgp/crs/misc/RL32701.pdf

Tierney, W. G. (1997). Organizational socialization in higher education. The Journal of Higher Education, 66(1) 1-16.

U.S. Department of Education. National Center for Education Statistics. Lifelong Learning NCES Task Force: Final Report, Volume I, Working Paper No. 2000-16a, by the NCES Lifelong Learning Task Force. Washington, DC: 2000.

United Nations Department of Economic and Social Affairs, Population Division. (2001). World population ageing 1950-2050. Retrieved from http://www.un.org/esa/population/publications/worldageing19502050/

Vogt, W. P. (2007). Quantitative research methods for professionals. Boston, MA: Pearson, Allen \& Bacon.

Walker, J. (Ed). (1996). Changing concepts of retirement: Educational implications. (Studies in educational gerontology). Burlington, VT: Ashgate Arena Publishing.

Waters, R. D. (2008) Applying relationship management theory to the fundraising process for individual donors. Journal of Communication Management, 12(1), 73-87.

Wheatley, M. J. (1999). Leadership and the new science: Discovering order in a chaotic world. San Francisco, CA: Berrett-Koehler Publishers.

Wilson, L. B., Harlow-Rosentraub, K., Manning, T., Simson, S., \& Steele, J. (2006, winter). Civic engagement and lifelong learning. Generations 30(4), 90-94. 
Wright, K. B. (2005). Researching internet-based populations: advantages and disadvantages of online survey research, online questionnaire authoring software packages, and web survey services, Journal of Computer-Mediated Communication, 10 (3), 1. https://doi.org/10.1111/j.1083-6101.2005.tb00259.x

Young, K. E. (1992). Post-retirement learning. In R. B. Fischer, M. L. Blazey, \& H. T. Lipman, (Eds.). Students of the third age (pp.13-24). New York, NY: American Council on Education and MacMillan Publishing Company. 


\section{APPENDIX A: SURVEY PARTICIPATION AGREEMENT}

\section{Dear OLLI /Osher Member:}

You are invited to participate in a research study titled Exploring the Relationship between Members of Lifelong Learning Institutes and Host Institutions.

You are receiving this invitation because you have been identified by your OLLI (Osher Lifelong Learning Institute) Director as a member of your OLLI /Osher.

This study is being conducted by Jon C. Neidy, former Director of the Osher Lifelong Learning Institute (OLLI) at Bradley University, and his dissertation research committee from the Department of Educational Administration and Foundations at Illinois State University.

Its purpose is to examine your relationship with your OLLI, including your frequency and types of participation, your satisfaction and feelings of community with your OLLI, and your experiences (if any) with financially supporting your OLLI / Osher or the institution that hosts your OLLI / Osher.

While you will not experience any direct benefits from participation, information collected in this study may benefit OLLIs nationwide in the future by better understanding relationships between members and OLLIs.

If you agree to participate, you will be asked to complete a brief electronic survey. Your participation in this study is voluntary and you are free to withdraw your participation from this study at any time. The survey should take only 10 minutes to complete.

This survey has been approved by the Institutional Review Board of Illinois State University and reviewed by the Osher National Resource Center Research Review Committee.

There are no risks associated with participating in this study beyond those you encounter in everyday life. The survey collects no identifying information of any respondent. All of your responses in the survey will be recorded anonymously. After your de-identified data has been collected, it will be used in doctoral dissertation research, and may be used in other research projects. The findings from this study will be disseminated anonymously.

To participate, please click on the "I consent" button below and complete the survey no later than August 23, 2019.

By completing and submitting this survey, you are indicating your consent to participate in the study

Because this survey does not collect any identifying information, you may receive periodic follow-up reminders from your OLLI Director. If you have completed the survey, you may disregard these. 
If you have any questions regarding this survey or this research project in general, please contact Jon C. Neidy at neidy@bradley.edu or his advisor Dr. Diane Dean at drdean@ilstu.edu.

If you have any questions concerning your rights as a research participant, please contact the IRB of Illinois State University at REC@ IllinoisState.edu.

Jon C. Neidy, Doctoral Candidate

Illinois State University Advisor Dr. Diane Dean

Department of Educational Administration and Foundations

Illinois State University 


\section{APPENDIX B: SURVEY QUESTIONS}

\section{Section 1: Participation and Demographics}

1. Which college or university hosts your OLLI or the OLLI where you spend the most time?

2. How long have you been participating in your OLLI?

3. Would you consider yourself an active member?

4. What is the highest degree or level of school you have completed?

5. Are you an alumnus / alumna of your OLLI Host Institution?

6. Your gender?

7. Your age?

8. Your ethnicity?

9. Approximately how many times within the past 12 months have you participated in OLLI activities, programs, or meetings?

10. Do you currently or have you ever served in a formal leadership role in your OLLI, such as member of its governing board, executive committee, or leadership team?

11. Do you currently or have you ever volunteered for your OLLI?

\section{Section 2: Satisfaction}

\begin{tabular}{l|l}
\hline Survey Question & Original Question \\
\hline 12. I am happy with my OLLI. & I am happy with this organization. \\
\hline $\begin{array}{l}\text { 13. OLLI and people like me benefit from our } \\
\text { shared relationship. }\end{array}$ & $\begin{array}{l}\text { Both the organization and people like me } \\
\text { benefit from the relationship. }\end{array}$ \\
\hline $\begin{array}{l}\text { 14. Most people like me are happy in their } \\
\text { interactions with OLLI. }\end{array}$ & $\begin{array}{l}\text { Most people like me are happy in their } \\
\text { interactions with this organization. }\end{array}$ \\
\hline $\begin{array}{l}\text { 15. Generally speaking, I am pleased with the } \\
\text { relationship that OLLI has established } \\
\text { with people like me. }\end{array}$ & $\begin{array}{l}\text { Generally speaking, I am pleased with the } \\
\text { relationship this organization has established } \\
\text { with people like me. }\end{array}$ \\
\hline $\begin{array}{l}\text { 16. Most people enjoy dealing with this } \\
\text { OLLI. }\end{array}$ & $\begin{array}{l}\text { Most people enjoy dealing with this } \\
\text { organization. }\end{array}$ \\
\hline $\begin{array}{l}\text { 17. I feel people like me are important to } \\
\text { OLLI }\end{array}$ & $\begin{array}{l}\text { I feel people like me are important to this } \\
\text { organization, }\end{array}$ \\
\hline
\end{tabular}




\section{Section 3: Commitment}

\begin{tabular}{l|l}
\hline $\begin{array}{l}\text { Survey Question } \\
\begin{array}{c}\text { 18. I feel that OLLI is trying to maintain a } \\
\text { long-term commitment to people like me. }\end{array}\end{array}$ & $\begin{array}{l}\text { Original Question } \\
\text { maintain a long-term commitment to people } \\
\text { like me. }\end{array}$ \\
\hline $\begin{array}{l}\text { 19. I can see that OLLI wants to maintain a } \\
\text { relationship with people like me. }\end{array}$ & $\begin{array}{l}\text { I can see that this organization wants to } \\
\text { maintain a relationship with people like me. }\end{array}$ \\
\hline $\begin{array}{l}\text { 20. There is a long-lasting bond between this } \\
\text { OLLI and people like me. }\end{array}$ & $\begin{array}{l}\text { There is a long-lasting bond between this } \\
\text { organization and people like me. }\end{array}$ \\
\hline $\begin{array}{c}\text { 21. Compared to other organizations, I value } \\
\text { my relationship with OLLI more. }\end{array}$ & $\begin{array}{l}\text { Compared to other organizations, I value my } \\
\text { relationship with this organization more. }\end{array}$ \\
\hline $\begin{array}{c}\text { 22. I would rather engage together in learning } \\
\text { with this OLLI than not. }\end{array}$ & $\begin{array}{l}\text { I would rather work together with this } \\
\text { organization than not. }\end{array}$ \\
\hline $\begin{array}{c}\text { 23. I feel a sense of loyalty to my OLLI. } \\
\text { 24. I feel a sense of loyalty to the } \\
\text { institution that hosts my OLLI. }\end{array}$ & I feel a sense of loyalty to this organization. \\
\hline
\end{tabular}

\section{Section 4: Communal Relationship}

\begin{tabular}{l|l}
\hline $\begin{array}{l}\text { Survey Question } \\
\begin{array}{l}\text { 25. OLLI enjoys giving others learning } \\
\text { opportunities. }\end{array}\end{array}$ & $\begin{array}{l}\text { Original Question } \\
\text { giving others aid. (Reversed) }\end{array}$ \\
\hline $\begin{array}{l}\text { 26. OLLI is very concerned about the learning } \\
\text { needs of people like me. }\end{array}$ & $\begin{array}{l}\text { This organization is very concerned about the } \\
\text { welfare of people like me. }\end{array}$ \\
\hline $\begin{array}{l}\text { 27. OLLI is very concerned about the social } \\
\text { needs of people like me. }\end{array}$ & \\
\hline $\begin{array}{l}\text { 28. I feel that OLLI is committed to people } \\
\text { who are interested in learning. }\end{array}$ & $\begin{array}{l}\text { I feel that this organization takes advantage of } \\
\text { people who are vulnerable. } \\
\text { (Reversed) }\end{array}$ \\
\hline $\begin{array}{l}\text { 29. I think that this OLLI succeeds by } \\
\text { engaging people like me. }\end{array}$ & $\begin{array}{l}\text { I think that this organization succeeds by } \\
\text { stepping on other people. } \\
\text { (Reversed) }\end{array}$ \\
\hline $\begin{array}{l}\text { 30. OLLI helps people like me without } \\
\text { expecting anything in return. }\end{array}$ & $\begin{array}{l}\text { This organization helps people like me } \\
\text { without expecting anything in return. }\end{array}$ \\
\hline $\begin{array}{l}\text { 31. I consider OLLI to be a particularly } \\
\text { helpful organization. }\end{array}$ & $\begin{array}{l}\text { I don't consider this to be a particularly } \\
\text { helpful organization. (Reversed) }\end{array}$ \\
\hline $\begin{array}{l}\text { 32. I believe the college or university that } \\
\text { hosts my OLLI values the program. }\end{array}$ & \\
\hline
\end{tabular}




\section{Section 5: Giving Behavior}

33. I have made one or more financial donations outside of my membership or fees to:

34. My total financial donation (outside of membership or fees) has been in the:

35. I have not made a financial donation (outside of membership or fees) to my OLLI nor the host institution because: 